\title{
Türkiye'de Konut Söylemlerinde Yaşanan Değişimin Reklamlar Üzerinden Analizi - İstanbul Örneği
}

\author{
Pınar Şahin \\ İstanbul Teknik Üniversitesi
}

\author{
Sinan Mert Şener \\ İstanbul Teknik Üniversitesi
}

Öz

Türkiye'de barınma biçimlerinde yaşanan değişimler sonucunda, günümüzde konut mekânı, üzerine yüklenen anlamlar aracılığıyla, bireyin toplumsal statüsünü ve yaşam tarzını belirleyen bir tüketim metası haline gelmiştir. Kuşkusuz, konutun üstlendiği bu yeni rolünde, sloganlar ve gerçeküstü görseller ile tüketici kitlelerini manipüle eden reklamların payı büyüktür. Reklamlar bir ürüne talep yaratma amacı güden anlam yapılar olmanın ötesinde, içerdikleri söylemlerle bulundukları toplumların egemen değerlerini yansıtan, dönemin siyasi, ekonomik ve sosyal yapısı hakkında ipuçları veren kültürel metinlerdir. Bu bağlamda, reklam söylemleri üzerinden konut anlayışında yaşanan değişimi okumak ve farklılaşan talepler doğrultusunda şekillenen konut üretim türlerini irdelemek bu araştırmanın temel amacıdır. Çalışma alanı olarak, gerek kentsel, gerek toplumsal bağlamda en dramatik değişimlere sahne olan İstanbul seçilmiştir. Araştırmada, Türkiye'de yayınlanan konut reklamlarının tarihsel süreçte, içerik bakımından nasıl yapılandırıldığının belirlenmesine yönelik olarak, iletişim çalışmalarında en çok tercih edilen yöntemlerden biri olan içerik analizi yöntemi uygulanmıştır. Bu çerçevede, reklamlar her dönemde içerdikleri söylemlere göre; mimariye yönelik söylemler, konum-ulaşım odakl söylemler, sosyal ve kültürel avantajlara yönelik söylemler, soyut söylemler, güvenlik odakl söylemler, teknik ve altyapıya yönelik söylemler ve satış-ödeme-yatırım odaklı söylemler olarak alt başlıklar halinde irdelenmiştir. Analiz kapsamında elde edilen sonuçlar, reklamlarm yayınlandıkları dönemin koşulları çerçevesinde değerlendirilmiştir. Bu bağlamda dönemlere ait reklamlar üzerinden yapılan analizler, değişen reklam imgelerinin belirlenmesi, neoliberal politikaların ve küreselleşme sürecinin öncesisonrasında yaşanan toplumsal ve mekânsal dönüşümlerin açıklanması bakımından önemlidir.

Anahtar Kelimeler: Konut reklamları, konut tüketimi, içerik analizi, konut söylemi, İstanbul. 


\title{
Analysis of the Changing Housing Discourses in Turkey over Advertisements - Istanbul sample
}

\author{
Pınar Şahin \\ İstanbul Technical University
}

\author{
Sinan Mert Şener \\ İstanbul Technical University
}

\begin{abstract}
As a result of the changing form of sheltering in Turkey, today housing has become a consumption material, which determine the social status and living style of a person, through the meanings that it assume. Definitely, advertisements, that manipulate the consumers with slogans and surrealistic images, have a big share in this situation. Beyond their role of being a meaning structure that aim to make a demand for a product, advertisements are cultural texts that give hints about the political, economic and social circumstances of a period and reflects the values of societies. In this context, reading the changing of housing approach on advertisement discourses and considering the housing production types in accordance with the changing demands, are the main purposes of this research. Istanbul was selected as a field of study which has become a stage of dramatic changes because of its urban and social context. In this study, in order to establish the content of the housing advertisements historically, content analysis was applied which is preferred frequently in communication works. In this context, for every period, advertisements were analyzed according to their discourses as; architecture oriented discourses, location-transportation oriented discourses, social and cultural advantages oriented discourses, abstract discourses, security oriented discourses, technic and infrastructure oriented discourses and sale-payment-investment oriented discourses. The results were considered in accordance with every period's conditions. The analysis is important in terms of determining the images of the changing advertisements and explaining the social and urban transformations that were lived beforelafter the globalization period and neoliberal politics.
\end{abstract}

Keywords: Housing advertisements, housing consumption, content analysis, housing discourse, Istanbul. 


\section{Giriş}

Konut genel olarak, "bir ya da daha çok insanın ikamet ettiği yer, ev, mesken, ikametgâh" şeklinde tanımlanabilir (Hasol, 2010, s.277). İnsanoğlu tarih öncesi çağlardan bugüne, kendini güvende hissedeceği, çevresel ve iklimsel koşullardan korunup yaşamını idame ettirebileceği bir mekân arayışı içerisinde olmuştur. Korunma amaçlı olarak başlayan bu arayış, zaman içerisinde toplumların ekonomik, politik ve kültürel düzlemde geçirdiği değişimlerle birlikte, barınma işlevinin ötesine geçmiş ve konut mekânı bulunduğu dönemin dinamiklerini yansitan simgesel bir rol üstlenmiştir. Mimarlığın giderek imaj oyunlarına dayalı bir yüzeyselliğe indirgendiği günümüz postmodern dünyasında, kentin çeşitli alanlarında hızla türeyen birbirinden farksız konut alanları, reklamlar aracılığı ile topluma birer ideal yaşam formatı olarak sunulmaktadır. Buna bağlı olarak, bireyin en temel ihtiyaçlarından biri olan barınma kavramı da değişmekte, konut barınma mekânı olmaktan öte imaj kaygısı güden bir tüketim metası olarak boy göstermektedir. Bu durum toplumun belleğindeki konut kavramını değiştirerek, mekânın imaj odaklı değerini artırmakta ve adeta bir konut modası yaratarak, günümüz tüketim ortamında mekânın anlamsal değerinin modanın geçiciliği içinde kaybolmasına yol açmaktadır. Kitleleri manipüle eden bir olgu olarak karşımıza çıkan reklamların toplumsal algıyı yönlendirmesi ile farklı kesimlerin belleğinde yarattığı anlamlar, beğenilerin de değişmesine sebep olmaktadır. Bugün inşaat şirketleri, mimari, fiziksel ve sosyal içeriği ile temalaştırılmış yeni konut alanlarının pazarlanmasında, reklam unsurunu etkili bir şekilde kullanmaktadır. Farklı kurgularla işlenmiş benzer konut projeleri, ideal yaşam tarzı olarak topluma sunulmakta, bunun sonucu olarak kent mekânı dramatik bir dönüşüme sahne olmaktadır.

Çalışma kapsamında ele alınan İstanbul'un geçirdiği tarihsel süreç göz önünde bulundurulduğunda, bugün kent mekânındaki çok katmanlı yapıyı, yaşanan dönüşüm üzerinden ifade etmek daha doğru olacaktır. Tanzimat'la beraber başlayan Batılılaşma hareketleri, Cumhuriyet ile birlikte daha da hız kazanmış, siyasi ve toplumsal yaşamda ortaya çıkan değişim, kentsel mekânda da kendini göstermiştir. Osmanlı Devleti'nin son dönemlerinde, Avrupa'dan esinlenerek inşa edilen ve başlarda gayrimüslim vatandaşların ikamet ettiği apartman yapıları, Cumhuriyet döneminde daha da yaygınlaşmış, apartmanlar modernleşme hareketinin yapısal ifa- 
deleri olarak kent mekânında yer almışlardır. Yeni geliştirilen yapım teknikleri ve apartmanın "modern yaşam temsili" olarak kentsel mekâna katılması ile başlayan bu süreç, İstanbul kent morfolojisinde yaşanan değişimin de başlangıcı olmuştur.

İkinci Dünya Savaşı sonrası toplumsal ve ekonomik değişimlerin sonucu olarak büyük kentlere göç eden nüfus, kent mekânında konut açığı problemini doğurmuştur. Yaşanan problemlere çözüm bulmak amaciyla, kent mekânı gerek kişisel girişimler gerek devlet eli ile yapılan müdahalelere sahne olmuş, kurulan Emlak Kredi Bankası ile birlikte, konutun medya ortaminda bir ürün olarak sunumunun ilk örnekleri sergilemiştir. Öte yandan bankalar tarafından mevduat karşıllğı çekiliş usulü ile verilen ikramiye evleri reklamları da ilk konut reklamı örneklerindendir. Tüm bu süreç, konutun metalaşması ve reklam mecrasında yer almasının ilk adımlarıdır.

1980'lerle birlikte Türkiye'de konut anlayışı yeni bir dönemece girmiştir. Yaşanan liberalleşme süreci, değişen sosyo-kültürel ortam ve orta sınıfın yaşadığı kimlik mücadelesi, kentin çeperlerinde hızla gelişen kapalı konut yerleşkelerinin oluşumunda büyük rol oynamıştır. Bu durum yeni zenginlere hayallerini kurdukları prestij, statü, gösteriş, lüks, rahatlık gibi kavramların gölgesinde, özel ve steril hayatlar sunmuştur. Böylelikle, toplumun geri kalanından ve geleneksel bağlarından kurtulma gayreti içinde olan üst gelir grubu, yeni sığınağını da bulmuştur. 2000'lere gelindiğinde ise, kentsel mekânda yaşanan ayrışmalar daha da belirginleşmiştir. Türkiye'nin içinde bulunduğu yeni sosyo-politik yapı, toplumsal muhalefetin cemaatler üzerinden şekillenmesine sebep olmuş, bu durum yeni söylemleri de beraberinde getirmiştir. "Kendi gibi" olanlarla birlikte yaşama anlayışı, konut mekânlarında ve dolayısıyla bir pazarlama söylemi olarak reklamlarda etkinleşmiştir. Daha önceleri sosyal statü, seçkinlik, zenginlik gibi daha çok gelir düzeyine yönelik tasarlanan reklam iletilerine artık, dönemin getirdiği sosyo-politik söylemler de eklenmiştir. Öte yandan, 2000'li yıllar kent merkezinin tekrar keşfedildiği dönem olarak da değerlendirilebilir. Önceki dönemde yaşanan kent merkezinden kaçış anlayışı belli oranda devam etse de, sosyal yapıdaki bireyselleşme ve aile yapısındaki değişim gibi faktörler kent mekânında yaşama olgusunu tekrar gündeme getirmiştir. Özellikle rezidans olarak nitelendirilen ve çok katlı bloklar içinde otel konforu vadeden yapıların kent mekanına girmesi ile kent merkezi önemli bir dönüşüme sahne olmuştur. 
Baudrillard (2012), tüketim toplumunda post modern insanın, gerçekte nesneleri tüketmekten çok, bunların ardındaki imgeleri, idealleri ve fantezileri tükettiğini savunur. Reklamlar da, dönemin koşulları ve değerleri çerçevesinde yarattıkları kodlar, simgeler ve etkili söylemler ile, toplumun tüketim alışkanlıklarını değiştirme potansiyelini kullanarak, çeşitli kurgularla işlenmiş konut projelerini, ideal yaşam tarzı olarak topluma empoze etmeye devam etmektedir. Toplum içerisindeki kültürel seçkinlik söyleminin inşasında önemli bir yeri olan konut reklamları, içerdiği görseller ve metinlerle, her dönemde önceki dönemlerdeki konut reklamlarından farklı söylemler ortaya koymuştur. Bu bağlamda dönemlere ait reklamlar üzerinden yapılacak analizler, değişen reklam imgelerinin belirlenmesi, neoliberal politikaların ve küreselleşme sürecinin öncesi-sonrasında yaşanan toplumsal ve mekânsal dönüşümlerin açılanması bakımından önemlidir. Dolayısıyla bu çalışmadaki amaç; bulundukları dönemin egemen toplumsal ve ekonomik koşullarının etkisi ile tarihsel süreçte değişim göstermiş olan konut reklamlarının, anlam ve ideolojisini kavramlar üzerinden irdeleyerek reklamlarda kullanılan söylemlerin, geçmişten günümüze ne şekilde değiş̧iklik gösterdiğini çözümlemektir.

\section{Yöntem}

Bu araştırmada, Türkiye'de yayınlanan konut reklamlarının tarihsel süreçte, içerik bakımından nasıl yapılandırıldığının belirlenmesine yönelik olarak, iletişim çalışmalarında en çok tercih edilen yöntemlerden biri olan içerik analizi (muhteviyat analizi) yöntemi uygulanmıştır. İçerik analizi bir veya bir dizi metin içerisinde belli kelimelerin/kavramların varlığını, kullanım sıklığını ve aralarındaki ilişkiyi belirlemek için kullanılan bir araştırma metodudur. Bu metotla araştırmacılar, belirledikleri kelimeler, kavramlar veya ibarelerin metin içerisindeki varlığını sayıya dökebilir, anlamları ve aralarındaki ilişkileri tahlil edebilir, metnin vermek istediği mesaj, yazarı, hatta metnin yazıldığı dönem hakkında çıarsamada bulunabilirler. (Acun, 2005, s.27) İçerik analizinin amacı, bir metni tasvir etmek ya da açıklamaktan ziyade, elde edilen kavram yoğunlukları ile döneme ilişkin çıkarımlar yapmaktır. Analiz sonucunda elde edilen nicel veriler, reklam metinlerinin kişisel yorumlardan sıyrılarak, objektif bir biçimde değerlendirilmesine olanak sağlar. 
Araştırma kapsamında, ulusal düzeyde yayın yapan gazete ve dergilerde yer alan reklamların yazılı ve görsel öğeleri ele alınmıştır. Bunun için reklam araştırmasında, uzun döneme yayılmış verilerin analizinde kullanılan tesadüfi örnekleme tekniğinden faydalanılmıştır. Üzerinde çalışılacak konut reklamlarının belirlenmesi için, Erken Cumhuriyet Dönemi'nden başlayarak 2016'ya kadar belirli bir kurala dayanmaksızın, olabildiğince her yıla ait bir konut reklamı sağlanacak şekilde, gazete ve dergiler taranmıştır. Reklamlar seçilirken, her dönem için en çok okunan gazete ve dergiler incelenmiş, analizin nesnel olması açısından aynı yaklaşım tüm dönemlerde uygulanmıştır. Bu bilgiler ışığında; Erken Cumhuriyet Dönemi'nde, 1950-1980 Dönemi'nde, 1980-2000 Dönemi'nde ve 2000 sonrası döneminde, gazete ve dergilerde yayınlanan, toplamda 102 adet konut reklamı seçilmiştir. Her reklam metnine ait kavramlar içerik ihtiva etmeyen terimler elenerek, tekli/ikili/üçlü ya da daha fazla kelime öbekleri halinde aşağıdaki söylem gruplarına göre sınıflandırılmıştır:

- Mimariye yönelik söylemler

- Konum-ulaşım odaklı söylemler

- Sosyal ve kültürel avantajlara yönelik söylemler

- Soyut söylemler

- Güvenlik odaklı söylemler

- Teknik ve altyapıya yönelik söylemler

- Satış-ödeme-yatırım odaklı söylemler

Yukarıdaki söylem grupları altında sıralanarak listeler haline getirilen tüm kavramlar, aşağıdaki kriterlere göre ölçülerek temel analiz matrisleri oluşturulmuştur:

- Kavramların tarihsel süreçte, içinde bulundukları söylem grubundaki frekansları ölçülerek diğer kavramlara göre yoğunluklarının belirlenmesi.

- Kavramların bulundukları tarihsel alt dönemler içerisinde, dâhil oldukları söylem grubundaki diğer kavramlara göre frekansları ölçülerek kullanım yoğunluklarının belirlenmesi.

Analizlerde elde edilen veriler, tablolarla birlikte kabarcık grafikleri de kullanılarak iki boyutlu düzleme aktarılmıştır. Kabarcık grafikleri, xy (dağlım) grafik tipinin değişik bir halidir. $X$ ve $Y$ koordinatlarında elde edilen verinin yanı sıra, kabarcık boyutu da değişken olduğundan, bu grafik türü dağılım grafiğinin noktalarına yeni bir ölçü katar. Böylelikle kabarcık 
grafiği ile kavramların, hem bulunduğu dönemde yayınlanan tüm reklamlar içerisindeki kullanım yüzdesi hakkında, hem de kendi söylem grubundaki diğer kavramlara göre kullanım yoğunluğu hakkında bilgi verici sonuçlara ulaşılır. Öte yandan, kronolojik düzlemde de söylemlerin kullanım yoğunluğunun takip edilmesine olanak tanıyarak, farklı dönemlere ait eğilimler hakkında bilgi verir. Söylemlerin frekans değerleri, içinde bulunulan döneme ait politik, ekonomik, sosyal ve kültürel yapı hakkında ipucu verir niteliktedir.

\section{Araştırma Bulguları}

\section{Konum-ulaşım odaklı söylemler}

İstanbul'da sermaye yaratmanın en kestirme yollarından biri haline gelen gayrimenkul piyasası ve kontrolsüz yapılaşma, kentin dengesiz ve plansız bir şekilde büyümesine sebep olmuştur. Kentin bu hızlı büyümesine, bazı bölgelerde yaşanan yı̆̆ılmalar da eklenince, ulaşım ciddi bir problem haline gelmiştir. Bu durum yeni yapılaşma hareketlerini tetiklemiş ve çok merkezli bir metropol haline gelen İstanbul için yeni ulaşım problemlerini de beraberinde getirmiştir.

Tablo 1. Konum-ulaşım odaklı söylemlerin Erken Cumhuriyet dönemi, 19501980 dönemlerine ait reklamlar içerisinde kullanım yoğunluğu.

\begin{tabular}{lcc|cc}
\hline \hline Söylem & \multicolumn{2}{c|}{ Erken Cumhuriyet dönemi } & \multicolumn{2}{c}{$1950-1980$ dönemi } \\
\cline { 2 - 5 } & $\begin{array}{c}\text { Kullanıldı̆̆ } \\
\text { reklam adedi }\end{array}$ & $\begin{array}{c}\text { Kullanıldı̆̆ } \\
\text { reklam yüz- } \\
\text { desi (\%) }\end{array}$ & $\begin{array}{c}\text { Kullanıldı̆̆1 } \\
\text { reklam } \\
\text { adedi }\end{array}$ & $\begin{array}{c}\text { Kullanıl- } \\
\text { diğı reklam } \\
\text { yüzdesi (\%) }\end{array}$ \\
\hline Tem ve E5'e yakınlık & $0 / 5$ & 0 & $0 / 38$ & 0 \\
Kadıköy'e yakınlık & $0 / 5$ & 0 & $0 / 38$ & 0 \\
Levent'e yakınlık & $0 / 5$ & 0 & $0 / 38$ & 0 \\
Toplu taşımaya yakınlık & $1 / 5$ & 20 & $4 / 38$ & 10.5 \\
İstanbul'un merkezi/kalbi & $0 / 5$ & 0 & $1 / 38$ & 2.6 \\
Kente yakınlık & $0 / 5$ & 0 & $1 / 38$ & 2.6 \\
\hline
\end{tabular}

Yapılan araştırma çerçevesinde öncelikli olarak konut reklamlarında geçen konum bilgileri ve ulaşıma yönelik söylemler üzerinde durulmuştur. Tüm söylem türleri göz önünde bulundurulduğunda, istisnasız her döneme ait reklamlarda konum ve ulaşıma dair söylemlerin yer aldığı görülmektedir. 1950'ye kadar incelenen sınırlı sayıdaki konut reklamında, daha çok toplu taşıma üzerine söylemlerin ön plana çıtı̆̆ı görülür. (\%20) 1950- 
1980 döneminde de yine ağırlıklı olarak toplu taşıma olanaklarına yönelik bilgiye rastlanmaktadır. (\%10.5) Örneğin, 1954 yılı Kartal Villaları reklamında 'önünde otobüs durağı', 'tren istasyonu ile vapur iskelesine yaya on dakika' gibi söylemler kullanılmıştır. Bunun dışında bu dönemde kente yakınlık ve merkezi konum olgularına dair söylemlerin başladığı dikkat çeker.

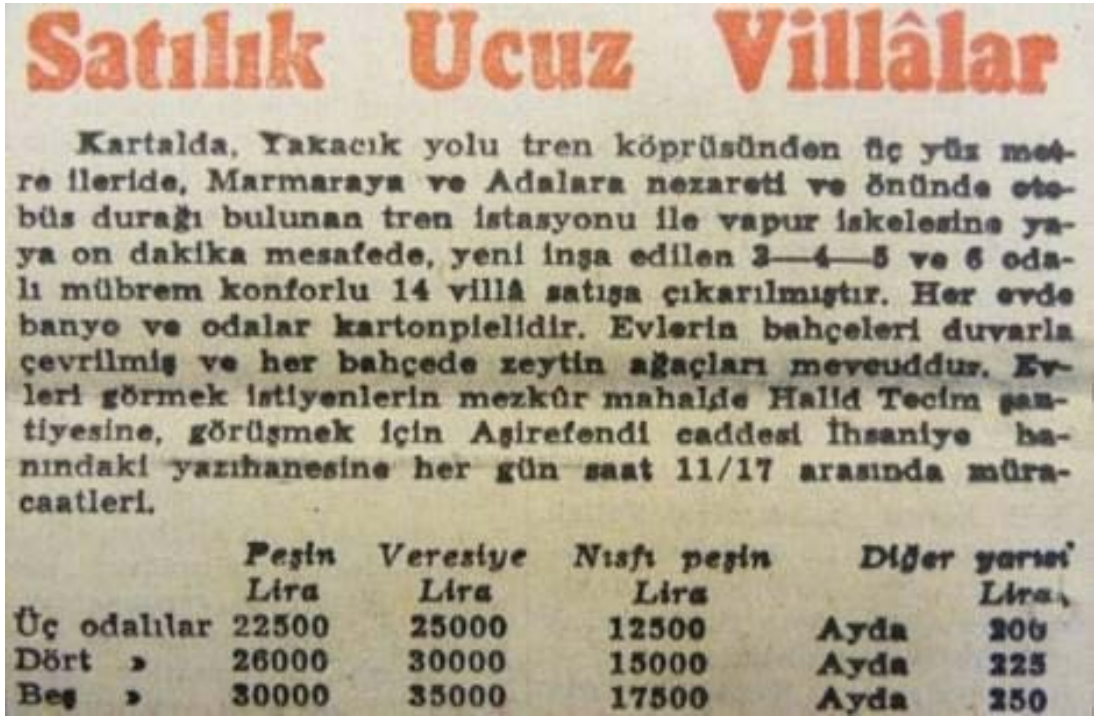

Şekil 1. Kartal Villaları reklamı (Cumhuriyet Gazetesi, 1954).

Tablo 2. Konum-ulaşım odaklı söylemlerin 1980-2000, 2000 sonrası dönemlerine ait reklamlar içerisinde kullanım yoğunluğu.

\begin{tabular}{lcc|cc}
\hline \hline Söylem & \multicolumn{2}{c|}{$1980-2000$ dönemi } & \multicolumn{2}{c}{2000 sonrası } \\
\cline { 2 - 5 } & $\begin{array}{c}\text { Kullanıldığı } \\
\text { reklam adedi }\end{array}$ & $\begin{array}{c}\text { Kullanıldığı } \\
\text { reklam yüzdesi } \\
(\%)\end{array}$ & $\begin{array}{c}\text { Kullanıldığı } \\
\text { reklam adedi }\end{array}$ & $\begin{array}{c}\text { Kullanıldığı } \\
\text { reklam yüz- } \\
\text { desi (\%) }\end{array}$ \\
\hline Tem ve E5'e yakınlık & $5 / 30$ & 16.7 & $6 / 29$ & 20.7 \\
Kadıköy'e yakınlı & $4 / 30$ & 13.3 & $0 / 29$ & 0 \\
Levent'e yakınlık & $2 / 30$ & 6.7 & $2 / 29$ & 6.9 \\
Toplu taşımaya yakınlık & $1 / 30$ & 3.3 & $5 / 29$ & 17.2 \\
İstanbul'un merkezi/kalbi & $5 / 30$ & 16.7 & $5 / 29$ & 17.2 \\
Kente yakınlık & $3 / 30$ & 10 & $3 / 29$ & 10.3 \\
\hline
\end{tabular}

1980-2000 yılları, ülkede yaşanan ekonomik hareketliliğe bağlı olarak, üst gelir grubuna hitap eden projelerin yoğunlukta olduğu bir dönemdir. Bu tip 
projelerin bulundukları konumlarından dolayı, Tem ve E-5'e olan bağlantıları ile ilgili söylemler reklam metinlerinde sıkça kullanılmaya başlanmıştır $(\% 16,7)$. Kente yakınlık söylemi de bu çerçevede artış göstermiştir. (\%10) Öte yandan, her ne kadar kent çeperlerinde yerleşimler artsa da, kent içindeki projelerde merkezi konum kavramı önemli bir avantaj olarak reklam metinlerinde yer almıştır. (\%16.7) Korkmaz Yiğit Yeşil Vadi Beldesi reklamında İstanbul'un ortasında tabiri bu bağlamda dikkat çekici bir örnektir.

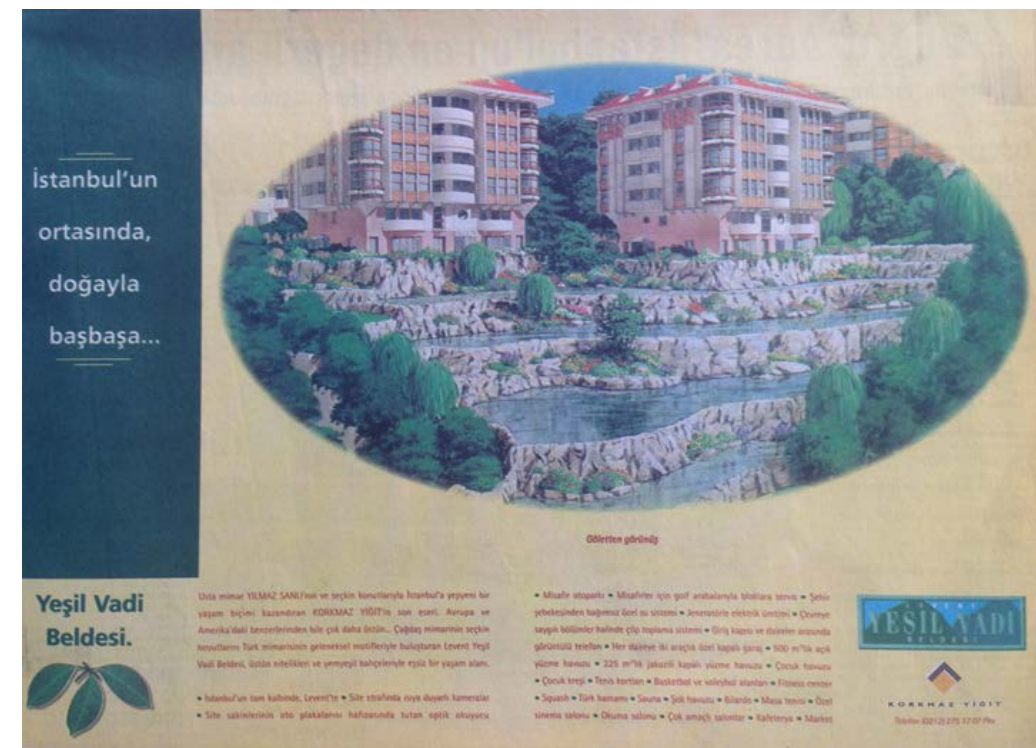

Şekil 2. Korkmaz Yiğit Yeşil Vadi Beldesi reklamı (Hürriyet Gazetesi, 1997).

2000 sonrası reklam metinlerine bakıldığında, merkezi konum, ana arterlere bağlantı ve toplu taşıma imkânları reklam metinlerinde daha çok ön plana çıkmaya başlamıştır. Kuşkusuz bunun en önemli sebepleri, kent sınırlarının gittikçe genişlemesi ve ulaşımın konut edinim kriterleri bağlamında daha önemli bir olgu haline gelmesidir. Bu çerçevede, 2000 sonrası yayınlanan reklamlarda, merkezi konum üzerine geliştirilmiş söylemler artış göstermiştir. $(\% 17,2)$ 'Kente yakınlık' ise bir önceki dönemle yaklaşık aynı oranlarda kullanılmıştır. Kente yakınlık olgusunun aksine, Tem, E-5 ve köprülerle bağlantılara dair söylemler artış göstermiştir. (\%20.7) Bunun sebebi olarak, son dönemde kent merkezine dönüş fikrinin güçlenmesi, dolayısıyla merkezden uzak olmayı ifade edecek söylemlerden kaçınılması düşünülebilir. Bu dönemde kent içi ulaşım olanaklarına yapılan vurgular da önemli ölçüde artmıştır. $(\% 17,2)$ 


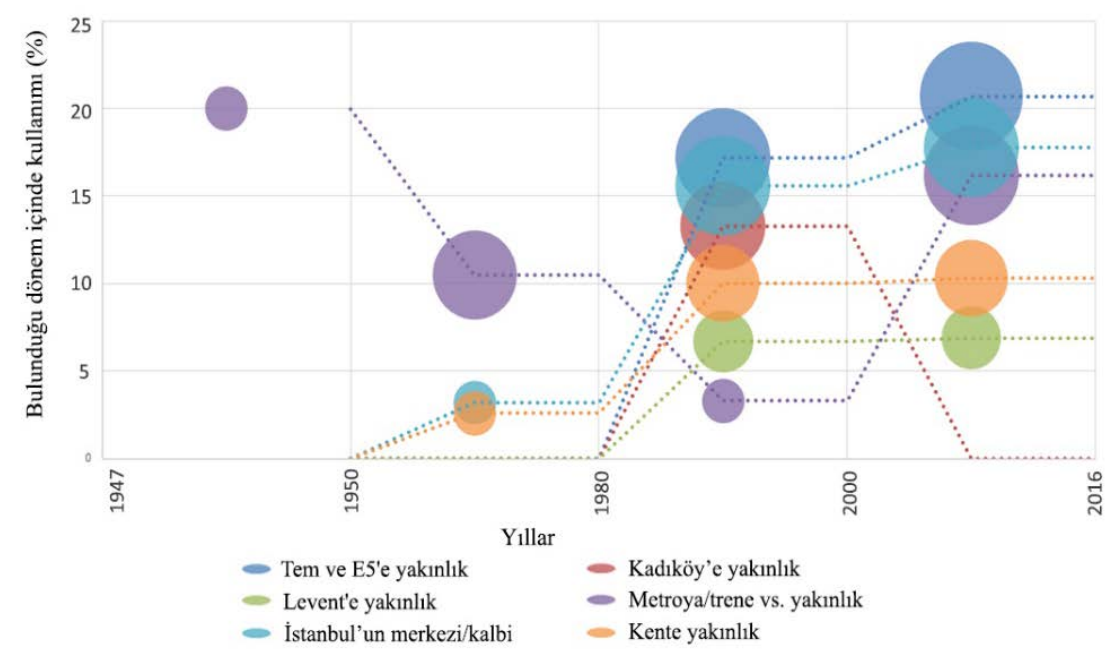

Şekil 3. Konum-ulaşım odaklı söylemlerin bulundukları dönemlerdeki kullanım yoğunluğu.

\section{Mimari ve yapısal özelliklere yönelik söylemler}

Mimari ve yapısal özelliklere yönelik söylemlerin tüm dönemlere ait reklamlar içerisinde kullanım yoğunluğuna bakıldığında, konut tipine yönelik söylemlerin daha sıklıkta kullanıldığı dikkat çeker. Bunu, konutun fiziksel özelliklerini belirten oda sayısı/ konut alanı ve iç mekân dekorasyon ögeleri takip eder.

Tablo 3. Erken Cumhuriyet dönemi ve 1950-1980 dönemlerinde reklamlarda yer alan mimari ve yapısal özelliklere yönelik söylemlerin kullanım yoğunluğu.

\begin{tabular}{|c|c|c|c|c|}
\hline \multirow[t]{2}{*}{ Söylem } & \multicolumn{2}{|c|}{ Erken Cumhuriyet dönemi } & \multicolumn{2}{|c|}{ 1950-1980 dönemi } \\
\hline & $\begin{array}{l}\text { Kullanıldığı rek- } \\
\text { lam adedi }\end{array}$ & $\begin{array}{c}\text { Kullanıldı̆̆ } \\
\text { reklam yüzdesi } \\
(\%)\end{array}$ & $\begin{array}{l}\text { Kullanildığı } \\
\text { reklam } \\
\text { adedi }\end{array}$ & $\begin{array}{l}\text { Kullanıldığı } \\
\text { reklam yüz- } \\
\text { desi (\%) }\end{array}$ \\
\hline Oda sayısı ve konut m2 & $1 / 5$ & 20 & $12 / 38$ & 31.6 \\
\hline $\begin{array}{l}\text { Konut tipine yönelik söylemler } \\
\text { (apartman, konak, vs.) }\end{array}$ & $1 / 5$ & 20 & $19 / 38$ & 50 \\
\hline $\begin{array}{l}\text { İç mekân ve dekorasyon öge- } \\
\text { leri (fayans, parke, vs.) }\end{array}$ & $0 / 5$ & 0 & $9 / 38$ & 23.7 \\
\hline $\begin{array}{l}\text { Tasarıma yönelik tanımlama- } \\
\text { lar (çağdaş, geleneksel) }\end{array}$ & $0 / 5$ & 0 & $1 / 38$ & 2.6 \\
\hline $\begin{array}{l}\text { Yapısal özellikler (yapım türü, } \\
\text { yalıtım, vs.) }\end{array}$ & $0 / 5$ & 0 & $3 / 38$ & 7.9 \\
\hline
\end{tabular}


Tablo 4. 1980-2000 ve 2000 sonrası dönemlerinde reklamlarda yer alan mimari ve yapısal özelliklere yönelik söylemlerin kullanım yoğunluğu.

\begin{tabular}{|c|c|c|c|c|}
\hline \multirow[t]{2}{*}{ Söylem } & \multicolumn{2}{|c|}{ 1980-2000 dönemi } & \multicolumn{2}{|c|}{2000 sonrasi } \\
\hline & $\begin{array}{l}\text { Kullanıldiğ1 } \\
\text { reklam } \\
\text { adedi }\end{array}$ & $\begin{array}{l}\text { Kullanıldığı } \\
\text { reklam yüz- } \\
\text { desi (\%) }\end{array}$ & $\begin{array}{l}\text { Kullanil- } \\
\text { diğı rek- } \\
\text { lam adedi }\end{array}$ & $\begin{array}{l}\text { Kullanıl- } \\
\text { diğ1 reklam } \\
\text { yüzdesi (\%) }\end{array}$ \\
\hline Oda sayısı ve konut $\mathrm{m} 2$ & $17 / 30$ & 56.7 & $10 / 29$ & 34.5 \\
\hline $\begin{array}{l}\text { Konut tipine yönelik söylemler } \\
\text { (apartman, konak, vs.) }\end{array}$ & $14 / 30$ & 46.7 & $14 / 29$ & 48.3 \\
\hline $\begin{array}{l}\text { İç mekân ve dekorasyon öge- } \\
\text { leri (fayans, parke, vs.) }\end{array}$ & $12 / 30$ & 40 & $5 / 29$ & 17.2 \\
\hline $\begin{array}{l}\text { Tasarıma yönelik tanımlamalar } \\
\text { (çağdaş, geleneksel) }\end{array}$ & $8 / 30$ & 26.7 & $7 / 29$ & 24.1 \\
\hline $\begin{array}{l}\text { Yapısal özellikler (yapım türü, } \\
\text { yalıtım, vs.) }\end{array}$ & $11 / 30$ & 36.7 & $3 / 29$ & 10.3 \\
\hline
\end{tabular}

Konut tipine yönelik söylemlerin dönemler içerisindeki değişimi incelendiğinde, 1950 yılına kadar yayınlanan reklamlarda genelde sadece 'ev' sözcüğünün kullanıldığı, 1950-80 döneminde ise 'apartman' kullanımının yoğunlaştığı görülür. (\%42,1) 1980-2000 arası, Türkiye için kapitalizmin kentsel mekânı keşfettiği dönem olarak nitelendirilebilir. Kentsel araziler değer kazanmış, mekânlar da artık birer tüketim nesnesi haline gelmiştir. Seçkinlik, farklılık, lüks gibi kavramlar yaşama mekânları için en sık kullanılan söylemler haline gelmiştir. Kapitalist sistemin konut mekânlarını etkileyen bu yeni tüketim anlayışı 'apartman' söyleminde de önemli bir düşüşe sebep olmuştur. Üst gelir grubunun merkezden uzak, kent çeperinde bulunan ve müstakil lüks konutlardan oluşan kapalı yerleşimleri tercih etmesi, 'villa' söyleminin daha yoğun olarak kullanımına sebep olmuştur. Öte yandan yeni tüketim kültürünün kent merkezindeki yapısal ifadesi olarak tanımlanabilecek olan 'rezidanslar' da bu dönemde ortaya çıkmıştır. 


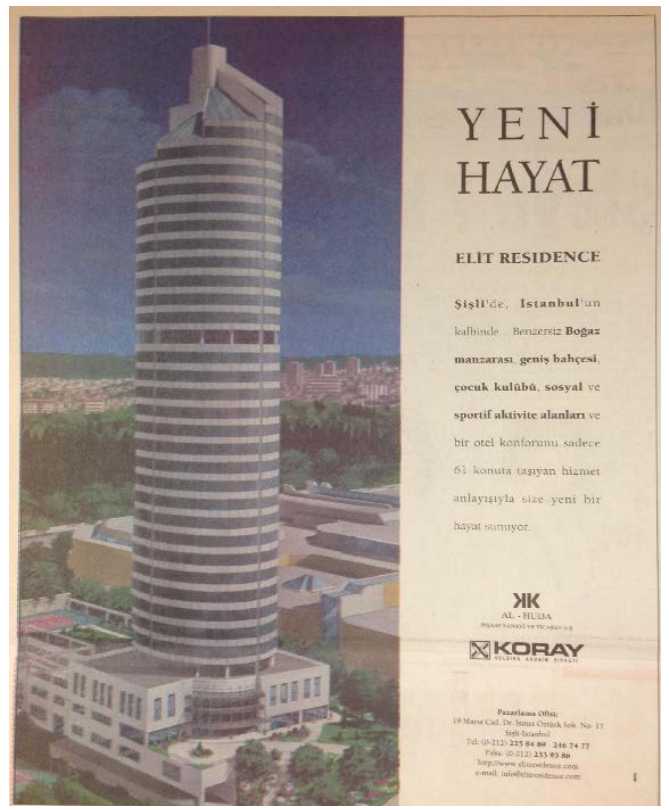

Şekil 4. Koray İnşaat Elit Residence reklamı (Hürriyet Gazetesi, 1999).
Geleneksel ve kültürel değerlerin yüceltilerek tüketime mal edildiği 1980-2000 arası dönemin yeni söylemlerinden biri de 'konak' olmuştur. Bazı projelerde konak mimarisine ait yapısal öğelere yer verilse de, bu dönemde 'konak' sözcüğü asıl olarak gelir seviyesini belirleyen bir söylem olarak kullanılmıştır. Villa, konak ve rezidans gibi söylemler, 2000 sonrası dönemde de varlıklarını sürdürmüşlerdir. 1980-2000 dönemindeki reklamlarda gittikçe azalan apartman söylemine ise 2000 sonrasinda rastlanmaz.

Yapılan araştırma dâhilinde yapısal özelliklere dair söylemler 1950-1980 döneminde reklamların \%7,9 gibi az bir kısmında kullanılırken, 1980-2000 döneminde bu oran \%36,7'ye yükselmiştir. Bu dönemde ağırlıklı olarak 'kaliteli inşaat malzemesi', 'betonarme karkas', 'su ve nem izolasyonu' gibi; daha çok kalite, yapım sistemi ve yalıtım konuları üzerinde durulmuştur. Bunun sebebi olarak, bu dönemde yeterli denetimlerin olmaması ve bu sebeple kalitesiz malzeme ve kötü işçilik gibi durumlara oldukça sık rastlanması gösterilebilir.

2000 sonrası için ise, yapısal söylemler açısından 1999 Marmara Depremi bir kırılma noktasıdır. Mevcut yapı stoğunun büyük bir bölümünün yeterli dayanıma sahip olmaması nedeniyle, yaşanan depremde büyük yapısal hasarla karşılaşılmıştır. Yapıların tasarımında ve inşasında yapılan hatalar, yetersiz yasal hükümler, düşük malzeme kalitesi ve kötü işçilik gibi nedenler, meydana gelen hasarın başlıca sebepleridir. Bu bağlamda, daha önceleri yapı güvenliği, deprem ya da zemin sağlamlığı konuları üzerine reklam metinlerinde herhangi bir söylem kullanmayan konut firmaları, deprem sonrasında özellikle bu konulara yoğunlaşmış ve reklam metinlerini ve senaryolarını bu doğrultuda geliştirmişlerdir. Özellikle 2000'lerin başlarında, 'çelik konstrüksiyon, 'sağlam zemin' ‘yurt dışından ithal yapım tekniği' gibi 
söylemlere sıklıkla rastlanmış, 2005'ten sonra ise hiç bir reklamda yapısal özelliklere dair bir söyleme ulaşılamamıştır.

Araştırma bulgularında, iç mekânda kullanılan malzemelere ve dekorasyon unsurlarına yönelik söylemlerin de sıklıkla kullanıldığı dikkat çeker. 1950-1980 arası konut reklamlarında kartonpiyer, ahşap parke, marley, gömme banyo, renkli seramik gibi söylemler kullanılmıştır. Proje özelliklerinin düz yazı formatında, ya da alt alta maddeler halinde sıralandığı bu reklamlar bilgi verici ifadeler içerir. 1980-2000 döneminde ise liberal ekonomi hareketlerinin başlaması ve ithalatın serbest kalması ile birlikte yapı elemanları da çeşitlilik göstermiştir. Bu dönemde yaşanan ekonomik, toplumsal ve kültürel değişiklikler dekorasyon anlayışını da etkilemiş, iç mekân tasarımında yeni eğilimler ortaya çıkmıştır. Kapalı lüks konut yerleşkelerine ait reklam metinlerinde, 'İtalyan seramik- karo döşeli mutfak', 'tabandan tavana fayans banyo', 'jakuzi' gibi yeni söylemlere rastlamak mümkündür. 2000'lerin başlarında da devam eden bu söylemler daha sonraları 'dekorasyon konsepti' başlığı altında genel olarak bazı reklam metinlerinde yer almıştır.

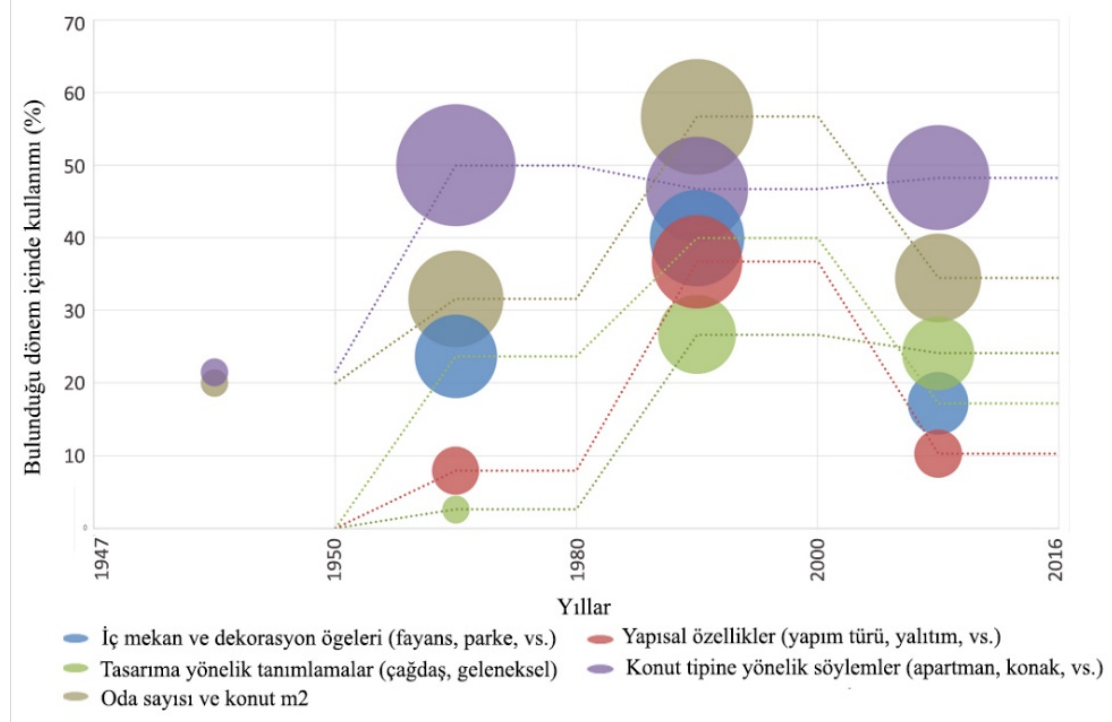

Şekil 5. Reklamlarda yer alan mimari ve yapısal özelliklere yönelik söylemlerin bulundukları dönemlerdeki kullanım yoğunluğu.

Mimari ve yapısal özelliklere dair yapılan araştırmada üzerinde durulan konulardan biri de, oda sayısı ve daire alanı gibi konutun büyüklüğüne ilişkin söylemler olmuştur. 1980-2000 dönemine ait reklamlarda bu tip verilere 
önemli ölçüde rastlamak mümkündür. Batıdaki konut anlayışından farklı olarak, konut alanı ve oda sayısı Türk insanı için en önemli konut edinim kriterlerinden biri olmuştur. Bu bağlamda, konutun Türk aile yapısına uygun planlama ve büyüklüğe sahip olması da önem kazanmıştır.

\section{Sosyal ve kültürel avantajlara yönelik söylemler}

Araştırma genelinde incelenen 102 adet reklamda; yeşil alan/doğa/su, alışveriş/ eğlence, çocuklara yönelik aktiviteler, eğitim, restoran/kafe, yürüyüş/bisiklet parkuru, spor alanları ve spa/masaj hizmetleri, sosyal ve kültürel avantajlara yönelik söylemler içerisinde ele alınan konulardır. Bu söylemlerin tüm dönemler içerisindeki kullanımı göz önünde bulundurulduğunda, gerek kullanım miktarı, gerek söylem çeşitliliği olarak 1980'lere kadar oldukça kısıtlı bir alana sahip oldukları görülmektedir. Kuşkusuz bunda 1980'lerin sonlarından itibaren başlayarak hızla yayılan kapalı konut yerleşkelerinin de etkisi büyüktür.

Konut reklamlarının geneli incelendiğinde en sık kullanıma sahip olan söylemlerin 'yeşil alan', 'su', 'peyzaj' gibi doğal öğeler olduğu göze çarpar. 1950'lerden önce yayınlanan kısıtlı sayıda reklamlarda \%60 gibi önemli bir kullanım yüzdesi olan bu söylem, 1950-1980 arasında \%23,7, 1980-2000 arasında \%63,3 ve 2000 sonrasında \%58,6 kullanım yoğunluğuyla toplamda olduğu kadar, bulunduğu her dönem içerisinde de en sık kullanılan sosyal ve kültürel olanaklara yönelik söylem olmuştur.

Yeşil alanlar yakın çevreleri ile kurdukları işlevsel ilişkilerin yanı sıra mekânsal olarak da çevresel kaliteyi olumlu yönde etkileyen bir olgudur. Özellikle konut çevresindeki yeşil alanlar estetik değerlerinin yanı sıra, kentsel dokunun düzenlenmesi gibi önemli işlevlere sahiptir. 1950'li yıllardan sonra, nüfus artışı ile birlikte bireylerin barınma taleplerini karşılamak amacıyla plansız bir şekilde gelişen kentleşme, yeşil alanların gittikçe azalmasına ve hatta yıllar geçtikçe özellikle kent merkezinde yok olmasına sebep olmuştur. Öte yandan konut anlayışındaki değişiklikler, müstakil konut yaşamının yerini hızla apartman yapılarının alması, yeşile duyulan özlemi artırmıştır. 1980'lerin sonlarından itibaren geniş arazi parçaları üzerinde yer alan kapalı konut yerleşkelerinin ortaya çıması ve reklamlarında yeşil alana gerek görsellerinde, gerek metinlerinde sıkça yer vermesi bu projelerin tercih edilme sebeplerinden biri olmuştur. Yeşil alanların gittikçe azalması ve yapılaşmış çevrenin artması, yeşil alan olgusunu bir ayrıcalık, hatta lüks haline getirmiştir. 
Tablo 5. Erken Cumhuriyet dönemi ve 1950-1980 dönemlerinde reklamlarda yer alan sosyal ve kültürel avantajlara yönelik söylemlerin kullanım yoğunluğu.

\begin{tabular}{lcc|cc}
\hline \hline Söylem & \multicolumn{2}{c}{ Erken Cumhuriyet dönemi } & \multicolumn{2}{c}{$1950-1980$ dönemi } \\
\cline { 2 - 5 } & $\begin{array}{c}\text { Kullanıldığı } \\
\text { reklam adedi }\end{array}$ & $\begin{array}{c}\text { Kullanıldı̆̆ } \\
\text { reklam yüz- } \\
\text { desi (\%) }\end{array}$ & $\begin{array}{c}\text { Kullanıldı̆̆1 } \\
\text { reklam } \\
\text { adedi }\end{array}$ & $\begin{array}{c}\text { Kullanıl- } \\
\text { diğı reklam } \\
\text { yüzdesi } \\
(\%)\end{array}$ \\
\hline Yeşil alan/doğa/su & $3 / 5$ & 60 & $9 / 38$ & 23.7 \\
Alışveriş/eğlence & $0 / 5$ & 0 & $2 / 38$ & 5.3 \\
Çocuklara yönelik aktivi- & $0 / 5$ & 0 & $1 / 38$ & 2.6 \\
teler & $0 / 5$ & 0 & $1 / 38$ & 2.6 \\
Eğitim & $0 / 5$ & 0 & $0 / 38$ & 0 \\
Restoran/kafe & $0 / 5$ & 0 & $0 / 38$ & 0 \\
Yürüyüş/bisiklet parkuru & $0 / 5$ & 0 & $0 / 38$ & 0 \\
Spor alanları & $0 / 5$ & 0 & $0 / 38$ & 0 \\
Spa/masaj hizmetleri & & &
\end{tabular}

Konutların kullanıcılarına sunduğu artı hizmetlerden biri de kuşkusuz spor alanlarıdır. Araştırma genelinde incelenen reklamlarda, 1980 yılına kadar gecen süreçte spor alanlarına dair bir söyleme rastlanmamıştır. 1980-2000 arası ise, konut reklamlarında spor olgusunun reklam metinlerinde bir avantaj olarak ifade edilmeye başlandığı dönemdir. (\%56.7) 2000 sonrasında da bu kullanım yoğunluğu devam etmiştir. (\%55.2)

Tablo 6. 1980-2000 ve 2000 sonrası dönemlerinde reklamlarda yer alan sosyal ve kültürel avantajlara yönelik söylemlerin kullanım yoğunluğu.

\begin{tabular}{lcc|cc}
\hline \hline Söylem & \multicolumn{2}{c}{$1980-2000$ dönemi } & \multicolumn{2}{c}{2000 sonrası } \\
\cline { 2 - 5 } & $\begin{array}{c}\text { Kullanıldı̆̆ } \\
\text { reklam adedi }\end{array}$ & $\begin{array}{c}\text { Kullanıldı̆̆ı } \\
\text { reklam yüz- } \\
\text { desi (\%) }\end{array}$ & $\begin{array}{c}\text { Kullanıldı̆̆ } \\
\text { reklam } \\
\text { adedi }\end{array}$ & $\begin{array}{c}\text { Kullanıldı̆̆1 } \\
\text { reklam yüz- } \\
\text { desi (\%) }\end{array}$ \\
\hline Yeşil alan/doğa/su & $19 / 30$ & 63.3 & $17 / 29$ & 58.6 \\
Alışveriş/eğlence & $11 / 30$ & 36.7 & $12 / 29$ & 41.4 \\
Çocuklara yönelik aktivi- & $12 / 30$ & 40 & $7 / 29$ & 24.1 \\
teler & $5 / 30$ & 16.7 & $3 / 29$ & 10.3 \\
Eğitim & $6 / 30$ & 20 & $11 / 29$ & 37.9 \\
Restoran/kafe & $5 / 30$ & 16.7 & $7 / 29$ & 24.1 \\
Yürüyüş/bisiklet parkuru & $17 / 30$ & 56.7 & $16 / 29$ & 55.2 \\
Spor alanları & $2 / 30$ & 6.7 & $8 / 29$ & 27.6 \\
Spa/masaj hizmetleri & & & & \\
\hline
\end{tabular}


İncelenen dönemlerin geneline bakıldığında konut reklamlarında sıklıkla kullanılan söylemlerden biri de çocuklardır. 1980'e kadar neredeyse hiç kullanılmayan, 1980 sonrası reklamlar genelinde \%40 kullanım oranına sahip olan çocuk söylemi, 2000 sonrasında \%24,1 ile yine önemli bir yüzdeye sahiptir. Bunun temel sebepleri olarak kent yaşamının gün geçtikçe daha zor bir hal alması, trafik, hava kirliliği, güvenlik gibi pek çok sorunun ortaya çıkması düşünülebilir. Çocuklar için eskiden doğal bir eylem olan 'sokakta oynamak', kentin yeni karmaşık düzeni ve kamusal mekânın gittikçe yok olması ile adeta bir lüks haline gelmiştir. Bu bağlamda, çocuk mekânları da bir ihtiyaç olarak gündeme gelmeye başlamış ve yeni konut projelerinin önemli söylemlerinden biri olmuştur.

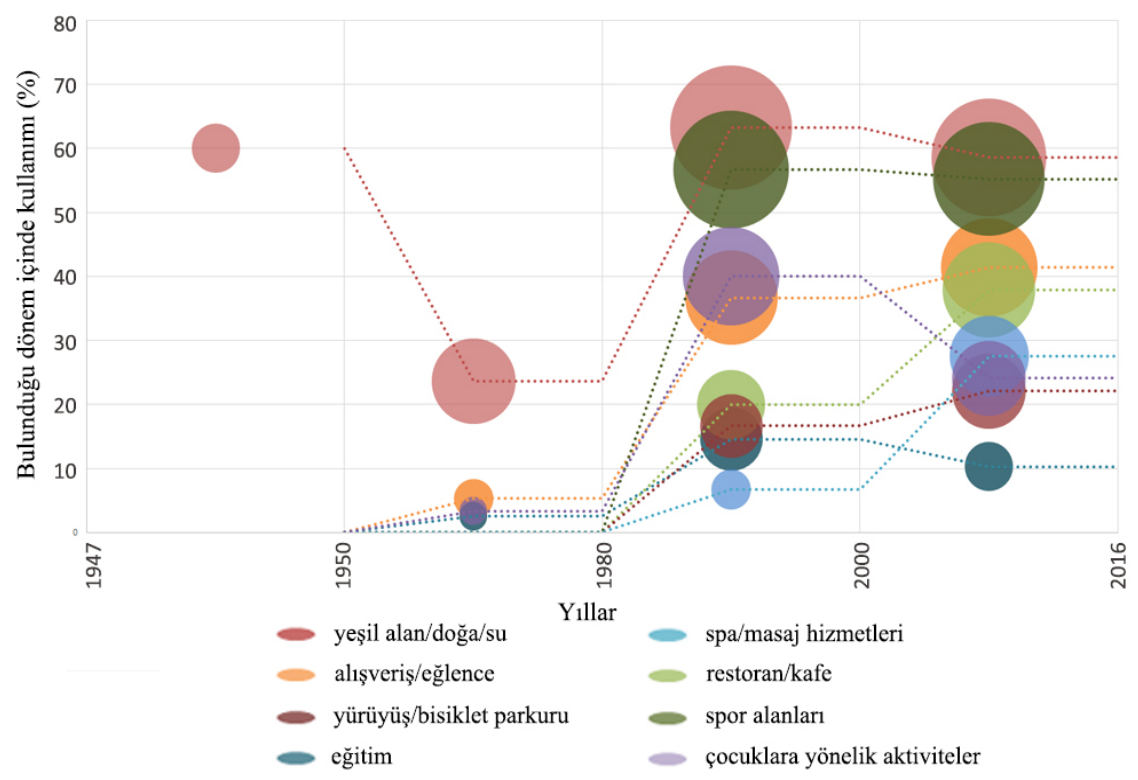

Şekil 6. Reklamlarda yer alan sosyal ve kültürel avantajlara yönelik söylemlerin bulundukları dönemlerdeki kullanım yoğunluğu.

Konut reklamlarında sıklıkla kullanılan bir diğer söylem ise alışveriş ve eğlence olanaklarıdır. 1950-1980 döneminde, çarşı ve gazino gibi, dönemin alışveriş ve eğlence kültürünü yansıtan kullanımlarıyla ortaya çıkan bu söylem 1980-2000 döneminde \%36.7, 2000 sonrasında ise \%41.4 kullanım oranıyla artış gösterir. Bu artışın sebebi olarak değişen tüketim kültürü ve yaşam alanları ile farklı fonksiyonların aynı yapıda bir araya gelmesi olarak düşünülebilir. Özellikle gelir düzeyi orta-üst ve üst sınıf 
ailelerin yaşamayı tercih ettikleri bu konut alanları, barınma işlevinin ötesinde tüketim odaklı merkezler olarak dikkat çekmektedir. 1980 sonrası liberal ekonomi hareketlerinin hayatın hemen her alanına yayılması ile birlikte, mahalle ölçeğindeki alışveriş mekânları, yerlerini önce büyük marketlere daha sonra ise avm lere bırakmıştır.

Yıllar içerisinde konuta barınma ihtiyacının ötesinde bir anlam yükleyen kapalı konut projeleri, özellikle 1990'lardan itibaren çok işlevli yapılarıyla birer alt kentleşme örneği sergilemektedir. Yukarıda belirtilen söylemlerin yanı sıra, eğitim, restoran, kafe, spa, hamam gibi söylemler de konut reklamlarında yer alan sosyal ve kültürel avantajlara yönelik söylemler çerçevesinde değerlendirilebilir.

\section{Soyut söylemler}

Reklamlar bir toplumdaki sosyo-ekonomik yapıyı, kültürel normları ve değerleri yansıtır. Bu bağlamda, metinlerde kullanılan soyut söylemlerin yıllar içerisinde geçirdiği değişimin belirlenmesi, yaşanan toplumsal, kültürel, sosyal ve hatta politik dönüşümler ile ilgili olarak bilgi vericidir.

Tablo 7. Erken Cumhuriyet dönemi ve 1950-1980 dönemlerinde reklamlarda yer alan soyut söylemlerin kullanım yoğunluğu.

\begin{tabular}{lcc|cc}
\hline \hline Söylem & \multicolumn{2}{c|}{ Erken Cumhuriyet dönemi } & \multicolumn{2}{c}{ 1950-1980 dönemi } \\
\cline { 2 - 5 } & $\begin{array}{c}\text { Kullanıldı̆̆1 } \\
\text { reklam adedi }\end{array}$ & $\begin{array}{c}\text { Kullanıldı̆̆1 } \\
\text { reklam yüz- } \\
\text { desi (\%) }\end{array}$ & $\begin{array}{c}\text { Kullanıldı̆̆ } \\
\text { reklam } \\
\text { adedi }\end{array}$ & $\begin{array}{c}\text { Kullanıldı̆̆1 } \\
\text { reklam yüz- } \\
\text { desi (\%) }\end{array}$ \\
\hline Lüks-konfor-kalite & $2 / 5$ & 40 & $17 / 38$ & 44.7 \\
Modern-çağdaş-medeni & $1 / 5$ & 20 & $5 / 38$ & 13.2 \\
Manzara & $0 / 5$ & 0 & $12 / 38$ & 31.6 \\
Güzel & $0 / 5$ & 0 & $5 / 38$ & 13.2 \\
Aile & $0 / 5$ & 0 & $2 / 38$ & 5.3 \\
Ayrıcalıkl1-farkl1-özel & $0 / 5$ & 0 & $1 / 38$ & 2.6 \\
Yaşam & $0 / 5$ & 0 & $0 / 38$ & 0 \\
Seçkin-düzeyli-elit & $0 / 5$ & 0 & $0 / 38$ & 0 \\
Huzur & $0 / 5$ & 0 & $0 / 38$ & 0 \\
Eşsiz-benzersiz & $0 / 5$ & 0 & $0 / 38$ & 0 \\
Tatil & $0 / 5$ & 0 & $0 / 38$ & 0 \\
\hline
\end{tabular}

1950 yılına kadar geçen süreçte yayınlanan sınırlı miktardaki reklamda ağırlıklı olarak 'konfor' (\%40) ve 'medeni' (\%20) söylemlerine rastlanmıştır. Ayrıca metinlerde döneme has, 'mutena semt', 'mübrem konfor', 'her konforu havi' gibi kullanımlar görülür. 1950-1980 arasındaki dönemde ise söylem çeşitliliği bir miktar artış gösterir. 'Lüks-konfor-kalite' söylemleri 
bu dönemde yoğun kullanılmıştır. (\%44.7) Ayrıca apartman tipi yapılaşmanın artış göstermesi ile birlikte 'manzara' da reklamlarda sık kullanılan bir başka söylem olmuştur. (\%31.6) Bu dönemde ortaya çıkan bir başka söylem de ailedir. Konut reklamlarının görsellerinde ve metinlerinde mutlu yuva ve aile olgusu üzerinde durulmuştur.

1980 sonrasında, gerek soyut söylem kullanımında, gerek söylem çeşitliliğinde ciddi bir artış göze çarpar. Konutun salt barınma işlevinin ötesinde bir anlayışla değerlendirilmeye başlandığı bu dönemde, konut artık sosyal statüsü ve tarzı olan bir yapıya dönüşmüştür. Özellikle 1990 sonrası yaşanan süreçte, artık konut reklamlarının en temel işlevlerinden biri 'tüketiciye bir kimlik sunmak' olmuştur. Bireyin içinde bulunduğu ortamın kendi için yetersiz olduğuna kanaat getirmesi, daha iyisini hak ettiğine inanması esasına dayanan reklam senaryoları, tüketicilere yeni ve farklı bir hayat sunmayı vaat etmeye başlamıştır. 1980-2000 arası reklam metinleri incelendiğinde, 'lüks' ve 'konfor', 'modern' gibi söylemlerin yanı sıra, artık yaşamı niteleyen söylemler dikkat çeker. 'Farklı yaşam', 'yeni yaşam biçimi', 'dolu dolu yaşam' gibi çok çeşitli söylemler dönem reklamlarında yoğun olarak yer almaya başlamıştır (\%26.7). Konutun, toplumsal konumlama ve kendini ifade etmenin sembolik aracı haline gelmeye başladığı bu dönemde yayınlanan reklamlar, sosyal sınıfları ve gelir seviyelerini belirginleştiren metinler de içerir. 'Seçkin-düzeyli-elit' (\%20) ve ayrıcalıkl1-farklı-özel (\%20) gibi söylemler bu dönemde ön plana çıkar.

Tablo 8. 1980-2000 ve 2000 sonrası dönemlerinde reklamlarda yer alan soyut söylemlerin kullanım yoğunluğu.

\begin{tabular}{lcc|cc}
\hline \hline Söylem & \multicolumn{2}{c|}{$1980-2000$ dönemi } & \multicolumn{2}{c}{2000 sonrası } \\
\cline { 2 - 5 } & $\begin{array}{c}\text { Kullanıldığ1 } \\
\text { reklam adedi }\end{array}$ & $\begin{array}{c}\text { Kullanıldı̆̆1 } \\
\text { reklam yüzdesi } \\
(\%)\end{array}$ & $\begin{array}{c}\text { Kullanıldığ1 } \\
\text { reklam } \\
\text { adedi }\end{array}$ & $\begin{array}{c}\text { Kullanıldı̆̆ } \\
\text { reklam yüz- } \\
\text { desi (\%) }\end{array}$ \\
\hline Lüks-konfor-kalite & $15 / 30$ & 50 & $11 / 29$ & 37.9 \\
Modern-çağdaş-medeni & $8 / 30$ & 26.7 & $0 / 29$ & 0 \\
Manzara & $5 / 30$ & 16.7 & $7 / 29$ & 24.1 \\
Güzel & $5 / 30$ & 16.7 & $3 / 29$ & 10.3 \\
Aile & $3 / 30$ & 10 & $2 / 29$ & 6.9 \\
Ayrıcalıklı-farklı-özel & $6 / 30$ & 20 & $12 / 29$ & 41.4 \\
Yaşam & $8 / 30$ & 26.7 & $14 / 29$ & 48.3 \\
Seçkin-düzeyli-elit & $6 / 30$ & 20 & $4 / 29$ & 13.8 \\
Huzur & $3 / 30$ & 10 & $3 / 29$ & 10.3 \\
Eşsiz-benzersiz & $3 / 30$ & 10 & $6 / 29$ & 20.7 \\
Tatil & $1 / 30$ & 3.3 & $6 / 29$ & 20.7 \\
\hline
\end{tabular}




\section{Bu kapinin arkasinda}

Avrupa standartannda, geleneksel

mimarimizle bütünleșmiș konaklar, günlük

yaşaminuz kolaylaștıracak sistemler, 24 saat

araliksı yônetim, genel bakm, onanm;

güvenliğiniz için bütü gün hizmete hazar

ozel ekip, cosskuyla yaşanacak bu hayat,

sizinle paylaşacak insanlar, ve tüm bunlan

tek bir ssococike anlatacak

konfor var.

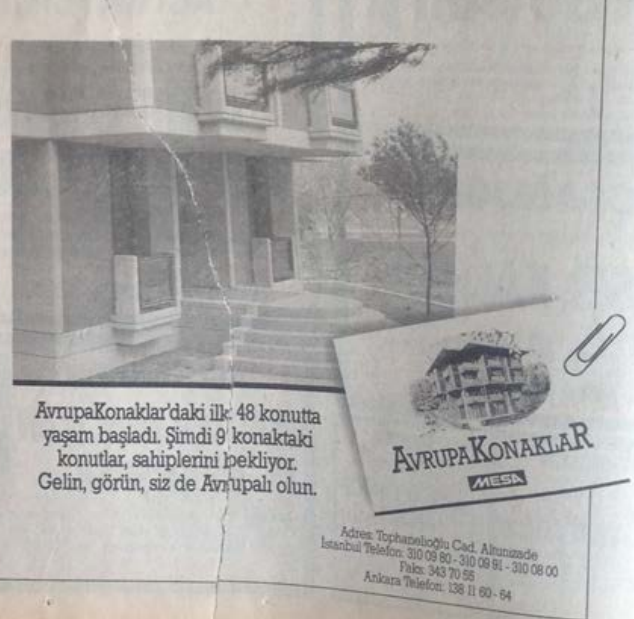

Şekil 7. Mesa Avrupa Konaklar reklamı (Hürriyet Gazetesi, 1991).

Birçok soyut söylem açısından, 1990'ların devamı olarak değerlendirilebilecek 2000'lere gelindiğinde, konut projeleri sayıca çoğalmış, buna bağlı olarak çok çeşitli mecralarda yayınlanmaya başlayan konut reklamları da artış göstermiştir. Aynı kategoride, benzer özelliklere sahip konut projeleri arasından sıyrılmak ve 'daha' olduğunu kanıtlamak gittikçe karmaşık bir hal almıştır. Artan rekabet, bilinçlenen tüketiciler ve yaşanan toplumsal, ekonomik ve politik gelişmeler, reklamcıları müşteri odaklı stratejiler geliştirmeye yöneltmiş, hedef kitleler farklı söylemler ile birbirinden ayrılmaya başlamıştır. Önceleri gelire ve dolayısıyla sınıfsal konuma göre şekillenen reklam metinleri, artık sosyal gruplara, etnisiteye ya da dini kimliğe göre imgeler barındırır hale gelmiştir. Geleneksel ve muhafazakâr yaşama dair, 'aile', 'huzur', 'geçmiş' gibi söylemler, ya da yalnız yaşamayı tercih eden modern kentli insanı hedef alan söylemler reklamlarda kullanılan görsellerle de pekiştirilmiştir. Yaşam üzerine geliştirilen söylemlerde ve 'ayrıcalıklı-farklı-özel' olmaya dair söylemlerde önemli oranda artış olmuş (\%48,3), hedef gruplara yönelik metinler oluşturularak tüketiciye mutlu yaşam vaatleri sunulmaya devam edilmiştir. 


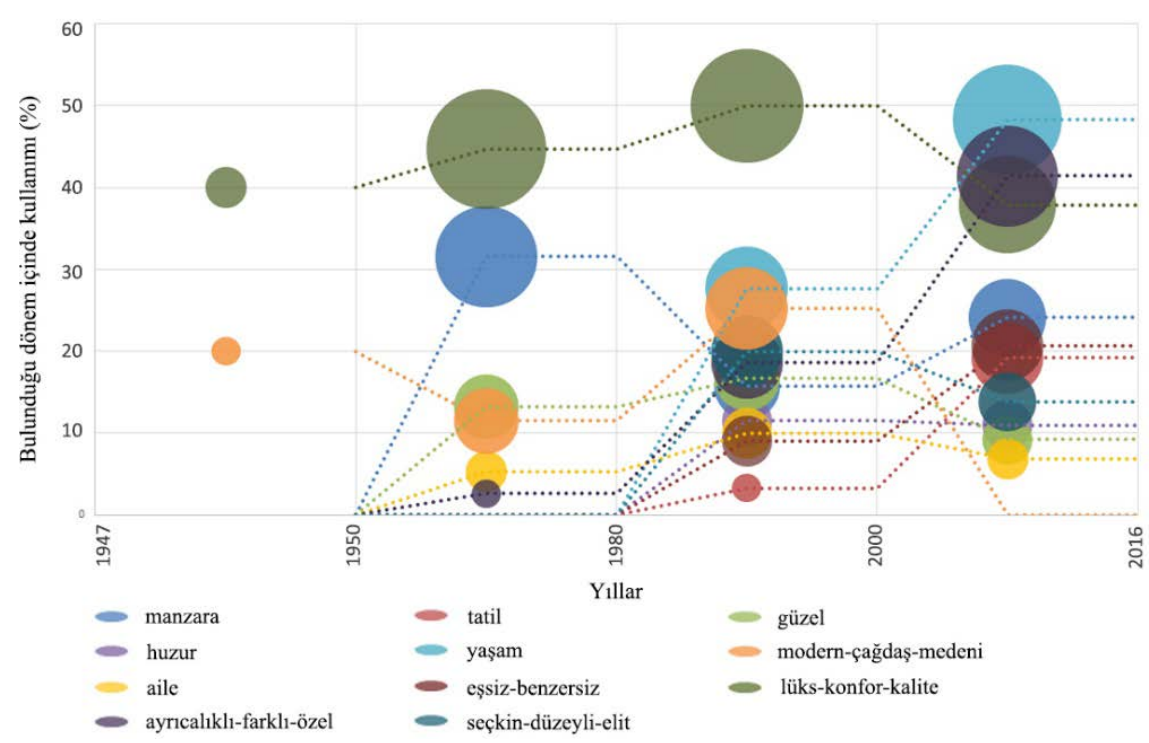

Şekil 8. Reklamlarda yer alan soyut söylemlerin bulundukları dönemlerdeki kullanım yoğunluğu.

\section{Güvenlik odaklı söylemler}

Araştırma genelinde ele alınan reklam içerikleri göz önünde bulundurulduğunda, güvenliğe dair söylemlerin 1980'li yıllara kadar kullanılmadığı, 1990'lardan sonra ise önemli ölçüde artış gösterdiği görülür. Bu durumu 1980 sonrasında ortaya çıkan dışa kapalı konut yerleşimleri ile açıklamak mümkündür. İstanbul'da özellikle 1960'lı yıllardan başlayarak yoğunlaşan dış göçlerden kaynaklı düzensiz ve hızlı nüfus artışı kültürel, ekonomik ve toplumsal yaşamda köklü değişimlere sebep olmuş, suç oranlarındaki artış, sosyal sınıflar arasındaki eşitsizlikler ve gerilimler kent mekânında güvenlik olgusunu gündeme getirmiştir. Üst gelir grubunun kendini izole etme çabası, benzer sosyo-ekonomik özelliklere ve tüketim alışkanlıklarına sahip insanlarla birlikte olma arzusu, dışa kapalı konut yerleşkelerinin oluşumunu sağlayan başlıca etkenler olmuştur. Kentin yeni güvensiz ve kalabalık ortamı yerine, güvenli, steril ve homojen bir yaşamın sunulduğu yüksek duvarlarla çevrili bu mekanlar 1980'lerin sonlarından itibaren reklam söylemlerine de konu olmuştur.

1980-2000 yılları arası yayınlanan konut reklamları değerlendirildiğinde, güvenlik söylemlerinin 1980'lerin sonlarından itibaren başladığ görülür. 'Güven' kelimesi yayınlanan reklamların \%16,7'sinde kullanıl- 
mıştır. Görevli güvenlik personelinin bulunduğuna dair, '24 saat güvenlik', 'özel güvenlik' gibi söylemler ise reklamların \%13,3'ünde yer alır. Reklamların \%13,3'ünde 'kapalı devre video', 'intercom sistemi', 'görüntülü telefon' gibi teknolojik sistemlere dair söylemlere yer verilmiştir.

Tablo 9. 1980-2000 ve 2000 sonrası dönemlerinde reklamlarda yer alan güvenlik odaklı söylemlerin kullanım yoğunluğu.

\begin{tabular}{|c|c|c|c|c|}
\hline \multirow[t]{2}{*}{ Söylem } & \multicolumn{2}{|c|}{ 1980-2000 dönemi } & \multicolumn{2}{|c|}{2000 sonras1 } \\
\hline & $\begin{array}{c}\text { Kullanildiğ } \\
\text { reklam } \\
\text { adedi }\end{array}$ & $\begin{array}{l}\text { Kullanıldığ } 1 \\
\text { reklam yüz- } \\
\text { desi (\%) }\end{array}$ & $\begin{array}{l}\text { Kullanil- } \\
\text { dığı rek- } \\
\text { lam adedi }\end{array}$ & $\begin{array}{l}\text { Kullanil- } \\
\text { diğı rek- } \\
\text { lam yüz- } \\
\text { desi (\%) }\end{array}$ \\
\hline Güvenlik & $3 / 30$ & 10 & $4 / 29$ & 13.8 \\
\hline Deprem & $1 / 30$ & 3.3 & $3 / 29$ & 10.3 \\
\hline Kamera kayıt sistemleri & $4 / 30$ & 13.3 & $2 / 29$ & 6.9 \\
\hline Yangin & $1 / 30$ & 3.3 & $1 / 29$ & 3.4 \\
\hline Güvenli & $1 / 30$ & 3.3 & $4 / 29$ & 13.8 \\
\hline Ak1lli ev & $0 / 30$ & 0 & $3 / 29$ & 10.3 \\
\hline
\end{tabular}

2000 sonrası dönemde 'güven' kelimesi kullanılmaya devam edilerek reklamların \%13,8'inde yer bulmuştur. Görevli güvenlik personelinin bulunduğuna dair, '24 saat güvenlik', 'özel güvenlik' gibi söylemler de reklamların yine \%13,8'inde kullanılmıştır. Yangın güvenliği söylemi ise reklamların \%3,4 gibi düşük bir oranında kullanılmıştır.

2000 'lerde konut reklamlarındaki söylemlere deprem güvenliği ve sağlamlık olgusu eklenmiştir. Özellikle 2000'lerin başında, 'deprem güvenliği' birçok konut alıcısı için ilk tercih unsurlarından biri olmuştur. Yapılan incelemede ele alınan 2000 sonrası reklamların \%13,8'inde deprem söylemi üzerinde durulmuş, hatta bu reklamlardan bazılarının tüm senaryosu deprem güvenliği üzerinden kurgulanmıştır. Daha önceleri bu konuda herhangi bir açıklamada bulunmayan konut firmaları, bu dönemde 'zemin etüdü', 'sondaj', 'çelik konstrüksiyon' gibi yapısal söylemlerle müşterilerin güvenini kazanmaya yönlenmiştir. İncelenen konut reklamlarında deprem söylemlerinin yer aldığı metinlerden bazıları aşağıdaki gibidir;

'Avrupa yakasının zemini en sağlam bölgesinde inşa edilen evlerde tünel kalıp teknolojisi kullanılıyor, böylece yapı güvenliği üst düzeye çıkıyor.' Mesa Kemerburgaz

'Her blokta sondajlı zemin etüdü yapılmıştır.' Ekşioğlu Esenşehir

'ABD-California'dan ithal, depreme dayanıklı hafif çelik konstrüksiyon.' Ömerlipark 
Akıllı ev teknolojisi ise 2000 sonrası konut reklamlarında kullanılan bir başka söylemdir. Akıllı ev ve otomasyon sistemleri, yaşanan mekânlara konfor sağlamakla birlikte, insan yaşamını ve malını tehdit edebilecek olaylarda önlem sağlayıcı ve kurtarıcı güvenlik fonksiyonları barındırırlar. Hırsızlık, gaz kaçağı, yangın, deprem gibi muhtemel acil durumlarda hem koruyucu hem de kurtarıcı özelliklere sahip olan bu sistemler 2000 sonrası konut reklamlarının \%10,3'ünde kullanılmıştır.

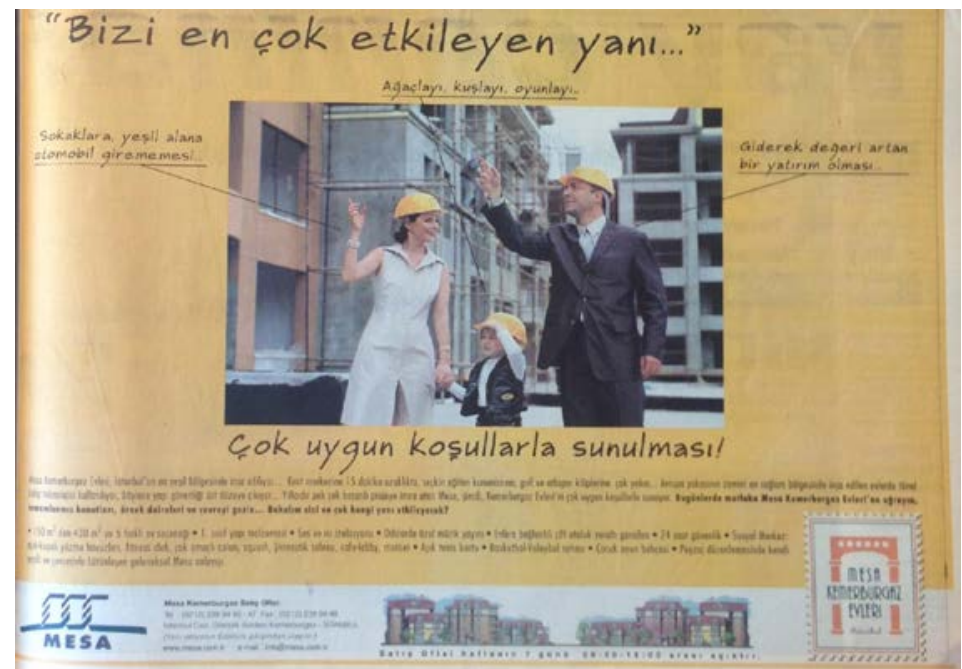

Şekil 9. Mesa Kemerburgaz reklamı (Hürriyet Gazetesi, 2001).

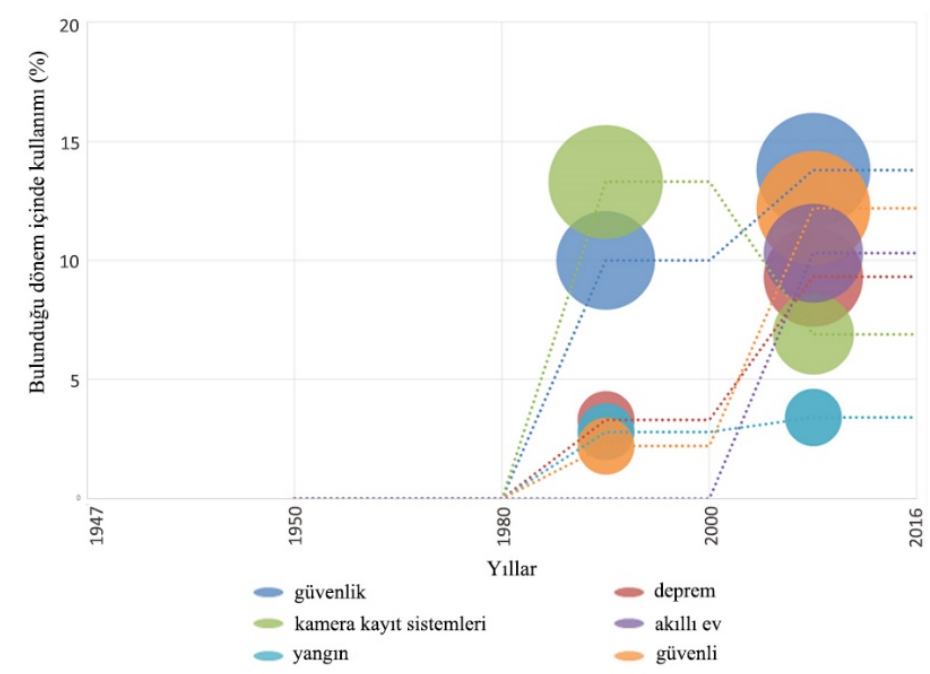

Şekil 10. Reklamlarda yer alan güvenlik odaklı söylemlerin bulundukları dönemlerdeki kullanım yoğunluğu. 


\section{Teknik ve altyapıya yönelik söylemler}

Kentlerin can damarları olarak nitelendirilen altyapı sistemleri, yaşanabilir çevrenin vazgeçilmez unsurlardır. 1950'ye kadar geçen süreçte, su, asfalt, elektrik gibi temel konfor ihtiyaçlarının yoğunlukta olduğu görülür. 1950 yılında yayınlanan Emlak Bankası Levent Evleri reklamında, 'muntazam asfalt yollar', 'modern kanalizasyon şebekesi', 'su, elektrik ve havagazı' gibi söylemlere rastlanır. 1960'a kadar geçen süreçte de bu söylemler kullanılmış, ilave olarak kalorifer söylemi eklenmiştir. 1960 sonrasında kalorifer ve asansör gibi söylemler daha yoğun kullanılmaya başlanmış, 1970 sonrasında ise bunlara otopark eklenmiştir.

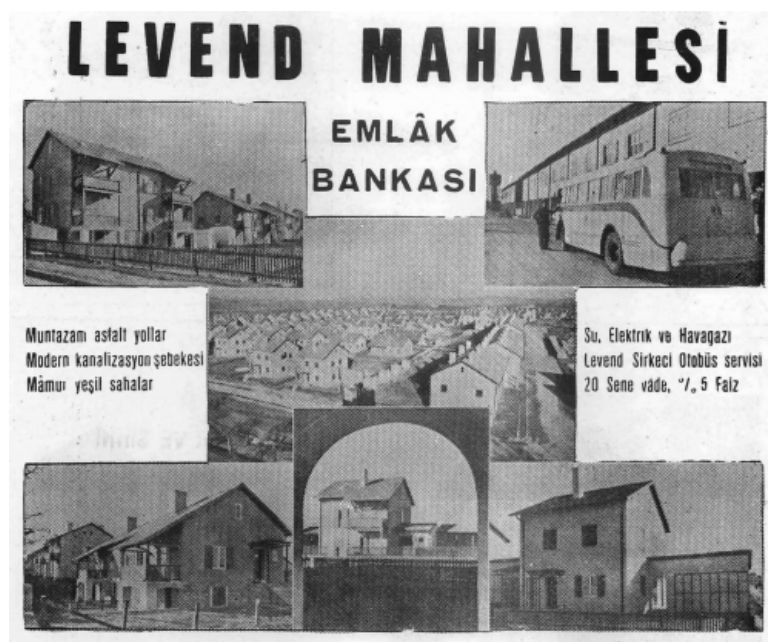

Şekil 11. Emlak Bankası Levend Evleri reklamı (Arkitekt Dergisi, 1950).

Tablo 10. Erken Cumhuriyet dönemi ve 1950-1980 dönemlerinde reklamlarda yer alan teknik ve altyapı olanaklarına dair söylemlerin kullanım yoğunluğu.

\begin{tabular}{lcc|cc}
\hline \hline \multirow{2}{*}{ Söylem } & \multicolumn{2}{c|}{ Erken Cumhuriyet dönemi } & \multicolumn{2}{c}{ 1950-1980 dönemi } \\
\cline { 2 - 5 } & $\begin{array}{c}\text { Kullanıldı̆̆ rek- } \\
\text { lam adedi }\end{array}$ & $\begin{array}{c}\text { Kullanıldı̆̆ rek- } \\
\text { lam yüzdesi (\%) }\end{array}$ & $\begin{array}{c}\text { Kullanıldı̆̆1 } \\
\text { reklam adedi }\end{array}$ & $\begin{array}{c}\text { Kullanıldı̆̆1 rek- } \\
\text { lam yüzdesi (\%) }\end{array}$ \\
\hline Su & $2 / 5$ & 40 & $2 / 38$ & 5.3 \\
Otopark & $0 / 5$ & 0 & $3 / 38$ & 7.9 \\
Asansör & $0 / 5$ & 0 & $3 / 38$ & 7.9 \\
Kalorifer & $0 / 5$ & 0 & $8 / 38$ & 21 \\
Asfalt & $2 / 5$ & 40 & $1 / 38$ & 2.6 \\
Elektrik & $2 / 5$ & 40 & $2 / 38$ & 5.3 \\
Anten & $0 / 5$ & 0 & $1 / 38$ & 2.6 \\
Akıllı ev & $0 / 5$ & 0 & $0 / 38$ & 0 \\
\hline
\end{tabular}


Tablo 11. 1980-2000 ve 2000 sonrası dönemlerinde reklamlarda yer alan teknik ve altyapı olanaklarına dair söylemlerin kullanım yoğunluğu.

\begin{tabular}{|c|c|c|c|c|}
\hline \multirow[t]{2}{*}{ Söylem } & \multicolumn{2}{|c|}{ 1980-2000 dönemi } & \multicolumn{2}{|c|}{2000 sonras 1} \\
\hline & $\begin{array}{l}\text { Kullanıldığı rek- } \\
\text { lam adedi }\end{array}$ & $\begin{array}{c}\text { Kullanıldığı reklam } \\
\text { yüzdesi (\%) }\end{array}$ & $\begin{array}{l}\text { Kullanıldığı } \\
\text { reklam adedi }\end{array}$ & $\begin{array}{l}\text { Kullanıldığı rek- } \\
\text { lam yüzdesi (\%) }\end{array}$ \\
\hline $\mathrm{Su}$ & $7 / 30$ & 23.3 & $0 / 29$ & 0 \\
\hline Otopark & $11 / 30$ & 36.7 & $5 / 29$ & 38.5 \\
\hline Asansör & $7 / 30$ & 23.3 & $0 / 29$ & 0 \\
\hline Kalorifer & $6 / 30$ & 20 & $0 / 29$ & 0 \\
\hline Asfalt & $0 / 30$ & 0 & $0 / 29$ & 0 \\
\hline Elektrik & $3 / 30$ & 10 & $0 / 29$ & 0 \\
\hline Anten & $6 / 30$ & 20 & $0 / 29$ & 0 \\
\hline Akıllı ev & $0 / 30$ & 0 & $3 / 29$ & 10.3 \\
\hline
\end{tabular}

1950-1980 döneminde yayınlanan reklamlarda kalorifer (\%21), asansör $(\% 9,2)$, otopark $(\% 7,9)$, su $(\% 5,3)$, elektrik $(\% 4,2)$, asfalt $(\% 3,6)$ ve anten $(\% 2,6)$ söylemlerine rastlanır. 1950-1980 y1lları arası, konut üretiminde yapsat ve kooperatifçiliğin yoğun olduğu bir dönemdir. Yapsat faaliyetlerini yürüten kişiler mümkün olan en kısa zamanda üretimlerini tamamlamaya ve yüksek kâr elde etmeye çalıştıkları için, konutların altyapısında ve teknik donanımlarında önemli eksiklikler olabilmektedir. Bu durum, dönemin reklam metinlerini de etkilemiş, teknik ve altyapıya dair söylemler kullanılarak, üretilen projenin niteliksel olarak hedef kitle üzerinde pozitif bir imaj oluşturması sağlanmaya çalışılmıştır. Bu dönemde konut mekânlarındaki en etkili değişimlerden biri de soba ile isıtılan konutlardan kalorifer ile ısıtılan konutlara geçişin gerçekleşmesidir. Ayrıca apartman yapılarında kullanılmaya başlanan asansör de dönemin önemli gelişmelerindendir. Bu dönemde görece lüks olarak tabir edilebilecek site ve apartman reklamlarında, asansör ve kalorifer gibi olanaklar üzerinde sıkça durulmuştur.

1980-2000 döneminde yayinlanan reklamlarda otopark (\%36,7), asansör $(\% 23,3)$, su $(\% 21,1)$, kalorifer $(\% 20)$, anten $(\% 18)$ ve elektrik $(\% 3,6)$ söylemlerine rastlanur. Yaşanan ekonomik ve teknolojik gelişmeler ile birlikte, taşıt sahipliğinin hızla artması sonucu otopark alanları konutlar için önemli bir sorun haline gelmiştir. Mevcut alt yapının yetersizliği de bu sorunu içinden çkılmaz hale getirmiş, dolayısı ile yeni geliştirilen konut projelerinde 'otopark' söylemi ön plana çıkmıştır. Asansör yine konut yapıları için önemli bir konfor kriteri olmuş, aynı şekilde anten söylemi de belli oranda devam etmiştir. Ay- 
rıca bu dönemde mevcut altyapı olanakları yetersiz kaldığından, su ve elektrik kesilmeleri gibi şikâyetlere çok sık rastlanmaktadır. Reklam metinleri de bu doğrultuda şekillenmiş, gelişen teknoloji ile birlikte bu problemlere çare olarak 'kesintisiz su-elektrik', 'jeneratör', 'hidrofor', 'özel su sistemi' gibi çeşitli çözüm içeren söylemler kullanılmıştır.

2000 sonrası konut reklamları incelendiğinde, konut alanlarının elektrik, su, kanalizasyon gibi temel düzeydeki teknik ve altyapı ihtiyaçlarının sağlanmasına dair söylemlere rastlanmaz. Projelerde artık altyapı hizmetleri en üst seviyede sağlanmaktadır ve ayırt edici bir nitelik taşımaz. Bu dönemde teknik ve altyapıya dair söylem çeşitliliği oldukça azalmıştır. 'Otopark' söylemi ise önemli ölçüde devam etmektedir (\%38,5). Ticaret ve işyerleri ile konut alanlarının aynı alanlarda yer alması, yaşanan yoğun trafik, yol üstü parklarına getirilen kısıtlamalar ve kişilerin araçlarını emniyetli ve uygun yerlere bırakma arzuları, otopark alanlarını projelerin olmazsa olmaz mekânları haline getirmiştir.

2000 sonrası dönemde ortaya çıkan bir diğer söylem de 'akıllı ev' sistemleridir $(\% 10,3)$. Yıllar içerisinde gelişen teknoloji ve yeni ihtiyaçların ortaya çıkması ile farklı kişilere yönelik, farklı fonksiyonlara sahip akıllı ev sistemleri geliştirilmiştir. Isıtma, aydınlatma, elektrik ve su gibi fonksiyonların dişarıdan kontrol edilebilmesi ve takip edilebilmesini mümkün kılan bu teknoloji reklam söylemlerinde de kullanılmaktadır.

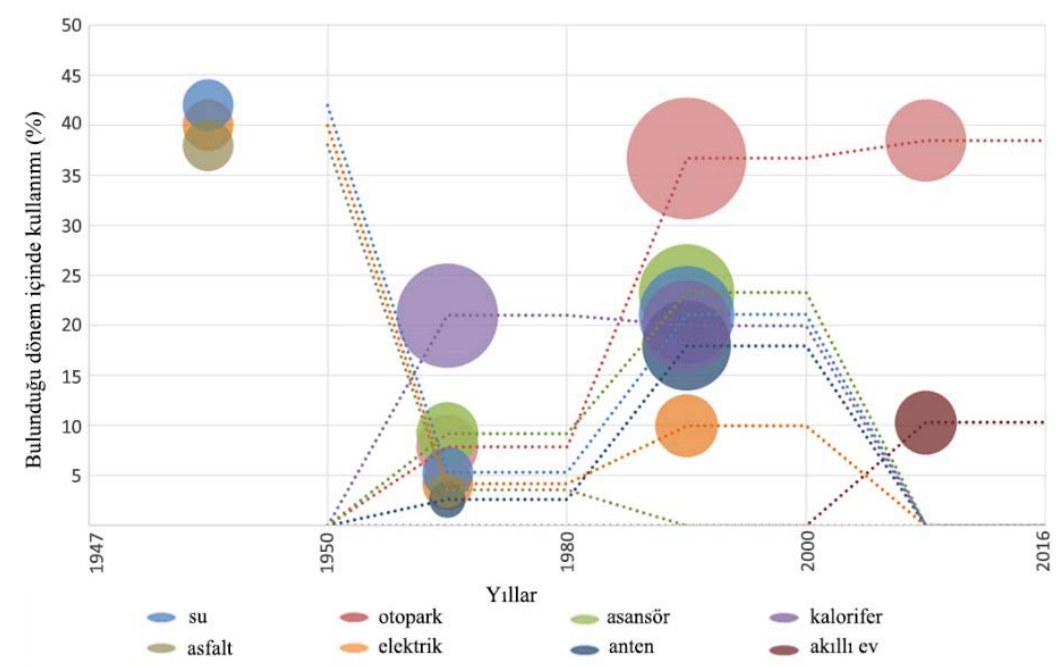

Şekil 12. Reklamlarda yer alan teknik ve altyapı olanaklarına dair söylemlerin bulundukları dönemlerdeki kulanım yoğunluğu. 


\section{Satış-ödeme-yatırım odaklı söylemler}

Konut reklamları kronolojik çerçevede değerlendirildiğinde, senaryoların ve söylemlerin her dönemde içinde bulundukları, kentsel, toplumsal, kültürel ve ekonomik koşullara göre değiştiği, ancak satış odaklı söylemlerin her dönemde kullanıldığ dikkat çeker. Bu gelişmeye etki eden faktörlerin başında sektörün karlılık oranının her geçen gün artması ve buna paralel olarak gayrimenkulün ülkemizde gittikçe en belirgin yatırım araçlarından biri olarak görülmesi gelmektedir.

Tablo 12. Erken Cumhuriyet dönemi ve 1950-1980 dönemlerinde reklamlarda yer alan satış-ödeme-yatırım odaklı söylemlerin kullanım yoğunluğu.

\begin{tabular}{|c|c|c|c|c|}
\hline \multirow[t]{2}{*}{ Söylem } & \multicolumn{2}{|c|}{ Erken Cumhuriyet dönemi } & \multicolumn{2}{|c|}{ 1950-1980 dönemi } \\
\hline & $\begin{array}{l}\text { Kullanıldığı rek- } \\
\text { lam adedi }\end{array}$ & $\begin{array}{l}\text { Kullanıldığı rek- } \\
\text { lam yüzdesi (\%) }\end{array}$ & $\begin{array}{l}\text { Kullanıldığı } \\
\text { reklam adedi }\end{array}$ & $\begin{array}{c}\text { Kullanıldığ } 1 \\
\text { reklam yüzdesi } \\
(\%)\end{array}$ \\
\hline Fiyat bilgisi & $1 / 5$ & 20 & $6 / 38$ & 15.8 \\
\hline Kredi & $0 / 5$ & 0 & $3 / 38$ & 7.9 \\
\hline Kooperatif & $0 / 5$ & 0 & $7 / 38$ & 18.4 \\
\hline İkramiye & $2 / 5$ & 40 & $9 / 38$ & 23.7 \\
\hline Satış ofisi & $0 / 5$ & 0 & $0 / 38$ & 0 \\
\hline Yatırım & $0 / 5$ & 0 & $0 / 38$ & 0 \\
\hline Örnek daire & $0 / 5$ & 0 & $0 / 38$ & 0 \\
\hline Uygun-makul & $0 / 5$ & 0 & $3 / 38$ & 7.9 \\
\hline
\end{tabular}

Tablo 13. 1980-2000 ve 2000 sonrası dönemlerinde reklamlarda yer alan satışödeme-yatırım odaklı söylemlerin kullanım yoğunluğu.

\begin{tabular}{|c|c|c|c|c|}
\hline \multirow[t]{2}{*}{ Söylem } & \multicolumn{2}{|c|}{ 1980-2000 dönemi } & \multicolumn{2}{|c|}{2000 sonrası } \\
\hline & $\begin{array}{l}\text { Kullanıldığı } \\
\text { reklam adedi }\end{array}$ & $\begin{array}{c}\text { Kullanıldığı } \\
\text { reklam yüzdesi } \\
(\%)\end{array}$ & $\begin{array}{l}\text { Kullanildığ } \\
\text { reklam } \\
\text { adedi }\end{array}$ & $\begin{array}{l}\text { Kullanıldığı } \\
\text { reklam yüz- } \\
\text { desi (\%) }\end{array}$ \\
\hline Fiyat bilgisi & $6 / 30$ & 20 & $9 / 29$ & 46.2 \\
\hline Kredi & $5 / 30$ & 16.7 & $7 / 29$ & 24.1 \\
\hline Kooperatif & $2 / 30$ & 6.7 & $0 / 29$ & 0 \\
\hline İkramiye & $0 / 30$ & 0 & $0 / 29$ & 0 \\
\hline Satış ofisi & $3 / 30$ & 10 & $9 / 29$ & 46.2 \\
\hline Yatırım & $2 / 30$ & 6.7 & $8 / 29$ & 27.6 \\
\hline Örnek daire & $3 / 30$ & 10 & $1 / 29$ & 3.4 \\
\hline Uygun-makul & $7 / 30$ & 23.3 & $2 / 29$ & 6.9 \\
\hline
\end{tabular}

1950'ye kadar gecen süreçte 'ikramiye' sözcüğü en yoğun kullanılan söylem olarak dikkat çeker. (\%40) Türkiye'deki yaygın tasarruf alışkanlık- 
larını değiştirmek ve 'yastık altı' olarak tabir edilen birikim yerine, bankalarda tasarrufa teşvik etmek amacı ile başta İş Bankası olmak üzere birçok banka reklamlar aracılığı ile ikramiye evleri çekilişleri düzenlemişlerdir. 'Keşide' (çekiliş) ve 'ikramiye' bu reklamlarda en sık kullanılan söylemler olmuşlardır. Bunun yanı sıra 'fiyat bilgisi' de reklamların \%20'sinde yer almaktadır. 1950-1980 döneminde de 'ikramiye' yine en çok kullanılan söylem olmuştur $(\% 23,7)$.

1950-1980 döneminde ortaya çıkan ve yoğun kullanımı olan bir diğer söylem de 'kooperatif' sözcügüüur. $(\% 18,4)$ Bireysel olarak konut sahibi olamayan dar ve orta gelirli kesim tarafından tercih edilen kooperatifler, bir finans havuzu oluşturarak, kâr amacı gütmeden konut üretebilme esasına dayalıdır. Başta Emlak Bankası ve Sosyal Sigortalar Kurumu olmak üzere, verdikleri krediler ile bu sürece destek vermiştir. Bu bağlamda 'kredi' de bu dönemde kullanılan söylemlerden biri olmuştur. $(\% 7,9)$ Özellikle 1969'dan sonra sigortalı kooperatif üyelerine verilen kredi miktarlarındaki artış, kooperatif reklamlarında da artışa sebep olmuştur. Fiyat bilgisi, yine bu dönemde yoğun kullanılan söylemlerden biridir (\%20). Özellikle kooperatif reklamlarında, yurt dışında yaşayan vatandaşlar da dikkate alınarak dolar, mark gibi yabancı para birimleri kullanılmıştır.

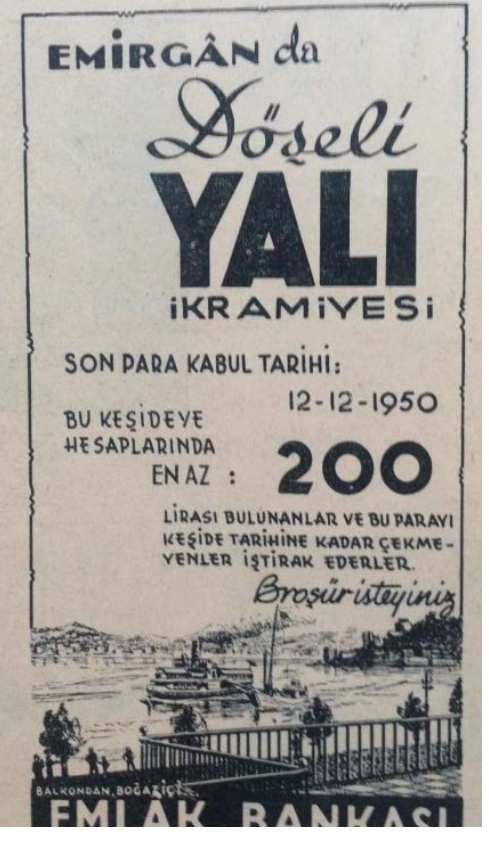

Şekil 13. Emlak Bankası Yalı İkramiyesi reklamı (Arkitekt Dergisi, 1950).
1980-2000 döneminde de fiyat bilgisi $(\% 20)$, kredi $(\% 16,7)$ ve kooperatif $(\% 6,7)$ söylemleri kullanılmaya devam etmiştir. Öte yandan bu dönem satış prensiplerinde de değişimin yaşandığı bir süreç olarak değerlendirilebilir. Daha önceki yılların reklam metinlerinde müşteriler inşaat şirketlerine ait bürolara ya da şantiyelere davet ediliyorken, 1990'lardan itibaren müşteri ilişkileri için satış ofisleri kullanılmaya başlanmış, reklam metinlerinde de bu söylem gündeme gelmiştir. (\%10) Bunun yanı sıra, projeye ait dairelerden birine ait iç mekân tasarımının ve dekorasyonunun tamamlanarak müşteriye sunulması esasına dayanan 'örnek daire' uygulaması da bu dönemde ortaya çıkmıştır. Örnek daire söylemlerine reklamların \%10'unda rastlanmaktadır. 


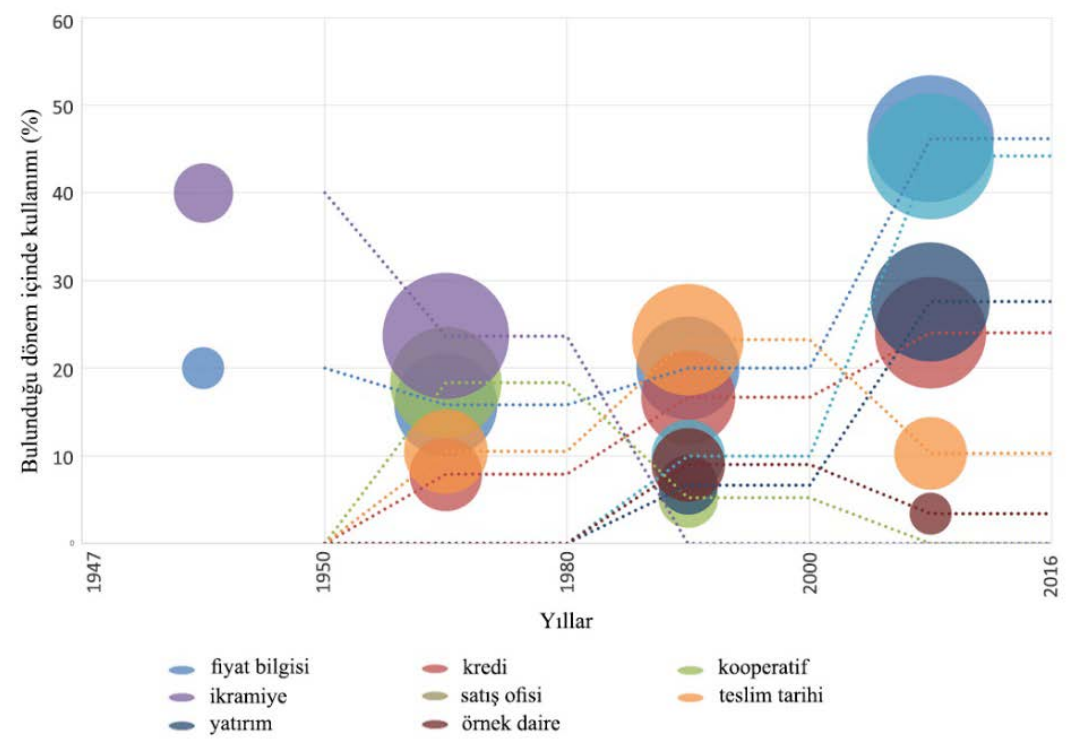

Şekil 14. Reklamlarda yer alan satış-ödeme-yatırım odaklı söylemlerin bulundukları dönemlerdeki kulanım yoğunluğu.

1980-2000 arası, birçok açıdan yeniliklerin ortaya çıtığı bir dönemdir. Konutun barınma işlevinden çıkarak bir yatırım metası olarak sunulması, ilk olarak bu döneme ait reklamlarda görülmektedir. Reklamların $\% 6,7$ 'sinde 'yatırım' söylemine rastlanmıştır. 2000 sonrası reklamlarda, fiyat bilgisi (\%46,2), satış ofisi $(\% 46,2)$, kredi $(\% 24,1)$, örnek daire $(\% 3,4)$ söylemleri kullanılmaya devam etmiştir. Öte yandan 'yatırım' sözcügü artış göstererek $(\% 27,6)$ ve en sık kullanılan söylemlerden biri olmuştur. Bu döneme ait reklam görsellerinde de yatırımı ifade eden ögelerin kullanımı, dikkat çekici bir unsur olarak karşımıza çıkar.

\section{Sonuç}

Her dönemde toplumun ideal konut anlayışının ve yeni yaşam hayalinin bir karşılığı olarak değerlendirilebilecek konut reklamları, gerçekle kurgu arasındaki sınırları muğlaklaştıran söylemleri ile konut anlayışının değişiminde önemli rol oynamışlardır. Literatür taramalarından da anlaşıldığ 1 üzere, önceki dönemlerde medyada sınırl sayıda yer alan konut reklamları, 1980 sonrası liberal dalgalanma ile yükseliş göstermiş, günümüzde ise hemen her mecrada yerini almıştır. Dış göçlere bağlı olarak İstanbul'un 
plansız bir şekilde hızla büyümesi, yaşanan konut açığı problemine çözüm olarak sunulan devlet müdahaleleri, konut kooperatiflerinin kuruluşu, yapsatçı üretim tipi ve son dönemde artan inşaat firmaları konut üretiminde yeni anlayışlar yaratmış, reklam metinleri de bu doğrultuda yapılanmıştır. Sanayi kapitalizmi, sekülerleşme ve modern toplumda kamusal-özel yaşamın değişen dengeleri gibi faktörler konutu, bireyin toplumsal, politik, kültürel bir izdüşümü olarak tekrar tanımlamıştır. Reklamlar ise tüm bu süreçte yaşanan dönüşümü metinlerinde yansıtarak, toplum beğenilerini yönlendirmeye devam etmişlerdir.

Reklamların toplumun tüketim alışkanlıklarına ve kapitalist yaşam anlayışının yaygınlaşmasına etkisi yadsınamaz bir gerçektir. Maslow'un ihtiyaçlar hiyerarşisinde de belirtildiği üzere, insan varoluşu gereği devamlı daha fazlasına isteme eğilimi gösterir. Fizyolojik ihtiyaçlar, güvenlik ihtiyaçları gibi temel gereksinimlerini karşılayan insan, sonrasında ait olma, sayg1 ve kendini gerçekleştirme gibi üst ihtiyaçlara yönelir. Konutun geçirdiği tarihsel süreç de benzer bir grafik sergiler. Barınma ihtiyacı ile ortaya çıkan konut mekânı, zaman içerisinde dönüşüm geçirmiş ve günümüzde temel ihtiyaçlar düzeyinin çok ötesine geçerek, bireyin kimliğini ve statüsünü simgeleyen bir unsur haline gelmiştir. Bu bağlamda, dönemlere ait reklamlar üzerinden yapılan analizler, değişen reklam söylemlerinin belirlenmesi, neoliberal politikaların ve küreselleşme sürecinin öncesisonrasında yaşanan toplumsal ve mekânsal dönüşümlerin açılanması bakımından önemlidir. İnsanoğlunun tüketim arzusu devam ettikçe, reklamlar içerdikleri görseller ve metinlerle, bulundukları dönemin dinamiklerini yansıtmaya devam ederek tekrar tekrar karşımıza çıkacaklar, kendisini hızla yapılandırmaya çalışan Türkiye'de kültürel söylemlerin inşasındaki varlıklarını sürdüreceklerdir. 


\section{Extended Abstract}

\section{Analysis of the Changing Housing Discourses in Turkey over Advertisements - Istanbul sample}

\author{
Pınar Şahin \\ İstanbul Technical University
}

\author{
Sinan Mert Şener \\ İstanbul Technical University
}

From prehistoric times to present, mankind has been searching for a place where he can feel safe, protect himself from environmental and climatic conditions and rescue his life. Along with the economic, political and cultural changes in society over time, this search goes beyond the need for sheltering and housing space has become a consumption item that determines the social status and lifestyle of the individual. Undoubtedly, advertisements that manipulate the consumer masses with slogans and surrealistic images, have a big share in this situation. Beyond their role of being a meaning structure that aim to make a demand for a product, advertisements are cultural texts that give clues about the political, economic and social structure of the period and reflects the values of societies. In this context, the main purpose of this study is to read the changes of housing phenomenon through advertising discourses and to investigate the types of housing production that are shaped from Early Republican Period to present. As the study area, Istanbul was chosen which has been the scene of the most dramatic changes both in the urban and social contexts.

The concept of housing in Turkey has started to break away from its traditional context since the late nineteenth century and urban space has entered into an important transformation process. The westernization movements that started with Tanzimat were accelerated with the Republic period and the changes in political and social life were also seen in the urban space. The process that started with the newly developed construction techniques and the participation of the apartment as a "modern living representation" in the urban space, have been the beginning of the change in Istanbul city morphology. In this period, in order to increase their deposits, banks arranged draws 
for account holders, by this way they brought the concept of "lottery houses" to the housing literature. The advertisements of the lottery houses published in newspapers and magazines, are the first examples of the presentation of the house as a product in the media environment. Also, discourses used in these advertisements, are informative about the economic, political and cultural structure of this period.

After 1950, the pace of industrialization, the formation of new employment areas, and the migration from rural to urban, led to an increase in the population of the city and thus to the inadequacy of housing stocks. In order to find solutions to the problems that have been experienced, urban space has become the scene of interventions, both by private initiatives and by government. In this period, cooperatives began to be built as new housing presentations. In parallel with all these developments, the housing advertisements which were published in the media increased and the advertising discourses were structured in this direction.

1980 's period indicates a new turning point for Turkey. Especially with the passing of the economy to the neoliberal form, a new era began in the understanding of consumption. New discourses emerging with the phenomenon of globalization, political-economic issues and social classes evolving with these effects have led to the emergence of new residential areas in the periphery of the city, designed for individuals who have similar social and cultural background. This has provided special and sterile lives in the shadow of concepts such as status, luxury, comfort that the new rich have dreamed of. The spatial composition of the neoliberal period has become more hierarchical compared to the previous periods and social groupings have begun to become readable through the urban space. The advertisement texts which had new discourses such as "different", "special", "prestige" and "secure", played an important role in deepening the social disintegrations by encouraging the principle of departing from the rest of the city.

2000 's can be considered as a new period in which social oppositions were shaped through different groups. In this period, conservative discourses have intensified and collective actions have left their places to groupings. The influence of government policies and the political structure of the period have been important facts for people's requirements of creating limited private areas and living as particular groups. Groupings in the social structure have also manifested itself in residential spaces and housing advertisements have begun to be presented with appropriate conservatism. The socio-political discourses have now been added to the advertising messages that were previously designed according to social status, elitism and wealth. 
In order to read the changing housing discourses periodically, determining the historical breakpoints is extremely important for the study. In this context, the data obtained in the analysis section were paraphrased as Early Republican Period, 1950-1980 Period, 1980-2000 Period and 2000-2016 Period. Therefore, a systematic infrastructure has been provided to analyze the meaning and ideologies of housing advertisements that have changed historically with the influence of the dominant social and economic conditions of the period they were in, and to analyze how the discourses used in advertisements varies from past to present.

In the research, content analysis method has been applied, which is one of the most preferred methods in communication studies, to determine how the housing advertisements in Turkey are structured in terms of content in the historical process. In this context, for every period, advertisements were analyzed according to their discourses as; architecture oriented discourses, location-transportation oriented discourses, social and cultural advantages oriented discourses, abstract discourses, safety oriented discourses, technical and infrastructure oriented discourses and sales-payment-investment oriented discourses. The results were considered in accordance with every period's conditions. In this context, analyzes based on advertisements are important in terms of determining the changing advertising discourses and explaining the social and spatial transformations that took place before and after the globalization period. When the limited academic works are taken into account about this subject, the importance of this research is better to understood.

\section{Kaynakça/ References}

Acun, F. (2005). Muhteva analizi metodu ve Cumhuriyet tarihi araştırmalarında kullanımı. Hacettepe Üniversitesi Edebiyat Fakültesi Dergisi, 22. 1, 27-50.

Barthes, R. (1999). Göstergebilimsel serüven. (M. Rufat, Çev.). İstanbul: Kaf Yayınları. (Orijinal eserin yayın tarihi 1985).

Batı, U. (2007). Kentin postmodernitesi, postmodern tüketim kültürü ışığında hedonik bir biçim olarak kent tasarımı. İstanbul Kültür Üniversitesi Güncesi, 5. 4, 1-16.

Batı, U. (2012). Reklamin dili, dilbilim-strateji-mesaj-retorik-göstergebilim. İstanbul: Alfa Yayınları.

Baudrillard, J. (2012). Tüketim toplumu. (H. Deliceçaylı ve F. Keskin, Çev.). İstanbul: Ayrıntı Yayınları. (Orijinal eserin yayın tarihi 1970).

Bektaş, C. (2003). Yuva mı mal mı? İstanbul: Tasarım Yayın Grubu.

Berger, J. (2013). Görme biçimleri. (Y. Salman, Çev.). İstanbul: Metis Yayınları. (Orijinal eserin yayın tarihi 1972). 
Çamdereli, M. (2013). Reklamın görme dediği. İstanbul: Avrupa Yakası Yayıncılık.

Dumont, P., Georgeon, F. (1996). Modernleşme sürecinde Osmanlı kentleri. İstanbul: Tarih Vakfi Yurt Yayınları.

Goldenberg, J., Levav, A., Mazursky, D., Solomon, S. (2013). Reklamın şifresini kırmak. (H. Mesci, Çev.) İstanbul: Optimist Yayınları. (Orijinal eserin yayın tarihi 2010).

Gürbilek, N. (2001). Vitrinde yaşamak -1980'lerin kültürel iklimi. İstanbul: Metis Yayınlar1.

Harvey, D. (2014). Postmodernliğin durumu. (S. Savran, Çev.). İstanbul: Metis Yayınları. (Orijinal eserin yayın tarihi 1997).

Hasol, D. (1997). Yağma var! İstanbul: Yapı-Endüstri Merkezi Yayınları.

Hasol, D. (2010). Ansiklopedik Mimarlık Sözlüğü. İstanbul : YEM Yayınları.

Kıray, M. (1998). Kentleşme yazıları. İstanbul: Bağlam Yayınları.

Kierkegaard, S. (2011). Kaygı kavramı. İstanbul: Türkiye İş Bankası Yayınları. (Orijinal eserin yayın tarihi 1843).

Keyder, Ç. (2000). İstanbul küresel ile yerel arasında. İstanbul: Metis Yayınları.

Kaynar, H. (2012). Projesiz modernleşme Cumhuriyet İstanbul'undan gündelik fragmanlar. İstanbul: İstanbul Araştırmaları Enstitüsü Yayınları.

Koç, E. (2007). Tüketici davranışı ve pazarlama stratejileri: global ve yerel yaklaşım. Ankara: Seçkin Yayınevi.

Merleau-Ponty, M. (2006). Göz ve tin. (A. Soysal, Çev.). İstanbul: Metis Yayınları. (Orijinal eserin yayın tarihi 1961).

Öncü, A. (1999). İdeal ev mitolojisi sınırları aşarak İstanbul'a ulaştı. Birikim Dergisi, 123, 26-34.

Özüekren, A.S. (1996). Kooperatifler ve konut üretimi. Y.Sey (Der.), Tarihten Günümüze Anadolu'da Konut ve Yerleşme içinde (ss. 355-365). İstanbul: Tarih Vakfı.

Rufat, M. (2009). Göstergebilimin ABC'si. İstanbul: Say Yayınları.

Simmel, G. (2003). Modern kültürde çatışma. (T.Bora, U. Özmakas, N. Kalaycı, E. Gen, Çev.). İstanbul: İletişim Yayınları. (Orijinal eserin yayın tarihi 1918).

Sullivan, L. (2014). Satan reklam yaratmak. İstanbul: Mediacat Yayıncılık. (Orijinal eserin yayın tarihi 2012).

Tanyeli, U. (2004). İstanbul 1900-2000: konutu ve modernleşmeyi metropolden okumak. İstanbul: Yapı Endüstri Merkezi Yayınları.

Tapan, M. (1996). Toplu konut ve Türkiye'deki gelişimi. Y.Sey (Der.), Tarihten Günümüze Anadolu'da Konut ve Yerleşme içinde (ss.366-378) İstanbul: Tarih Vakfı.

Tekeli, İ. (2011). Türkiye'nin kent planlama ve kent araştırmaları tarihi yazıları. İstanbul: Tarih Vakfi Yurt Yayınları.

Tekeli, İ. (1982). Türkiye'de kentleşme yazıları. Ankara: Turhan Kitabevi Yayınları.

Tekeli, İ. (2010). Konut sorununu konut sunum biçimleri ile düşünmek. İstanbul: Tarih Vakfi Yurt Yayınları.

Yaylagül, L. (2010). Kitle iletişim kuramları. Ankara: Dipnot Yayınları.

Zaltman, G. (2016). Tüketici nasıl düşünür? (A.S. Koç, Çev.). İstanbul: MediaCat Yayınları. (Orijinal eserin yayın tarihi 2003). 
Zaltman, G., Zaltman L., (2008). Pazarlama metaforları: pazarlamanın yeni çă̆ında tüketicinin zihnini anlamak. (Ü. Şensoy, Çev.). İstanbul: Optimist. (Orijinal eserin yayın tarihi 2008).

Pınar Şahin: 2006 yılında Yıldız Teknik Üniversitesi Mimarlık Fakültesi Mimarlık Bölümü'nden lisans, 2008 yılında ayn üniversitenin Bina Bilgisi Programı'ndan yüksek lisans derecesi almıştır. Yüksek lisans eğitiminin ikinci yılında Technische Universiteit Eindhoven' da tez öğrencisi olarak yer almış ve Rotterdam'ın kentsel markalaşma süreci üzerine çalışmıştır. Türkiye'ye döndükten sonra çeşitli şirketlerde mimar olarak görev almıştır. 2018 yılında İstanbul Teknik Üniversitesi Mimari Tasarım Programı'nda doktora eğitimini tamamlamıştır. Profesyonel iş hayatının yanısıra 2017'den itibaren Bahçeşehir Üniversitesi Mimarlık Bölümü'nde yarı zamanlı öğretim görevlisi olarak çalışmaktadır. İlgi alanları konut araştırmaları, konut tüketimi, kentleşme politikaları, modernite ve kültür kuramlarıdır.

She graduated from Yildiz Technical University (YTU) Faculty of Architecture, Department of Architecture in 2006. She got her Master of Science degree from Building Design and Theory Programme at YTU in 2008. In the second year of her master education, she studied as a thesis student at Technische Universiteit Eindhoven and worked on Rotterdam's urban branding process. After returning to Turkey she worked as an architect in various companies. In 2018 she got her Phd degree from Architectural Design Programme at Istanbul Technical University. In addition to her professional works in the market, she has been working as a part-time lecturer at Bahcesehir University Architecture Department since 2017. Her interests are housing researches, housing consumption, urbanization policies, modernity and culture theories.

E-mail: pinarsahinarch@gmail.com

Sinan Mert Şener: 1982 yılında İstanbul Teknik Üniversitesi Mimarlık Fakültesi Mimarlık Bölümü'nden lisans, 1984 yılında aynı üniversitede yüksek lisans derecesi aldı. 1984-88 yılları arasinda serbest mimarlık faaliyetlerinde bulundu. 1994'te İstanbul Teknik Üniversitesi'nde Doktor unvanı aldı. 1995-1997 yılları arasında Yardımcı Doçentlik, 1997-2011 yılları arasında Doçentlik yaptı. 1998-99 yıllarında Carnegie Mellon Üniversitesinde PostDoc yaptı. 2011 yılında Profesör unvanı aldı. 2000-2008 yılları arasında İstanbul Teknik Üniversitesi'nde Dekan Yardımcılığı ve 20122016 yılları arasında Dekanlık yaptı. Halen İstanbul Teknik Üniversitesi'nde görev yapmakta olan Prof. Dr. Sinan Mert Şener' in basılmış makaleleri, bildirileri ve kitapları vardır. İlgi alanları algoritmik tasarım, biçim gramerleri, üretken sistemler ve mimari tasarımdır.

He graduated from Istanbul Technical University (ITU) Faculty of Architecture, Department of Architecture in 1982 and he got his Master of Science degree in 1984. Between1984-1988 he worked as an independent architect. He got his PhD degree at ITU in 1994. He worked as an Assistant Professor between1995-1997 and as an Associate Professor between1997-2011. He conducted his post-doctoral studies in Carnegie Mellon University, between 1998-1999. In 2011 he was appointed as Professor. He served as Deputy Dean between 2000-2008 and as Dean between 2012-2016 at Istanbul Technical University. Prof. Dr. Sinan Mert Sener still works at Istanbul Technical University and he has several published journals, papers and books. His interests are algorithm design, shape grammars, productive systems and architectural design.

E-mail: sinanmertsener@gmail.com

\section{Kaynakça Bilgisi / Citation Information}

Şahin, P. \& Şener, S. M. (2018). Türkiye'de konut söylemlerinde yaşanan değişimin reklamlar üzerinden analizi - İstanbul örneği. IDDEALKENT - Kent Araştırmaları Dergisi, 23, 258-291. 